\title{
An indicator framework to support comprehensive approaches to sustainable fisheries management
}

\author{
Eric Angel $^{1,2}, \underline{\text { Danielle N. Edwards }}^{3}, \underline{\text { Sarah Hawkshaw }}^{3}, \underline{\text { Catarina Wor }}^{3}$ and Courtenav E. Parlee $^{4,5}$
}

\begin{abstract}
Indicator-based frameworks for assessing the sustainability of commercial fisheries have become well-established in the consumer sector. Within fisheries management, there are only a few jurisdictions, notably Australia, where sustainability frameworks are regularly used across the full spectrum of management functions, including planning, decision making, and evaluation. In Canada, a "sustainable fisheries framework" has been proposed but implementation has been limited to date. The Canadian Fisheries Research Network (CFRN), a six-year collaboration between Fisheries and Oceans Canada (DFO), the commercial fishing industry, and academic institutions, included as one of its major outputs the development of a comprehensive framework-based approach to evaluate the sustainability of commercial fisheries in Canada. Although most fisheries sustainability frameworks focus on the ecological domain, the CFRN explicitly recognized the social, economic, and institutional domains as having equal importance in a holistic treatment of sustainability. Following an iterative research and development process, a subgroup within the CFRN produced a novel sustainability indicator framework that combines a hierarchical subject matter structure consisting of domains, dimensions, and elements with a formula approach to developing indicators that utilizes a system of variables, or attributes. These two aspects of the sustainability indicator framework are linked in a way that helps to enforce comprehensive and routine methods for identifying objectives and relating those to specific indicators. The careful balancing of scope and depth makes for a powerful tool that can be used across a range of fisheries management contexts within Canada and in other jurisdictions that have a similar governance structure and high degree of institutional capacity. We present a detailed account of how the sustainability indicator framework was developed, the logic of its construction, and its potential application in fisheries management.
\end{abstract}

Key Words: fisheries; framework; indicators; sustainability

\section{INTRODUCTION}

A significant shortcoming of most existing approaches to sustainable fisheries management is the narrow definition of sustainability. Although in theory sustainability should include social, cultural, institutional, and ethical dimensions of fisheries, too often the scope of sustainability in fisheries is limited to a small set of biological and economic considerations (Stephenson et al. 2018, also see Barnett 2018, Foley et al. 2018). This is true in spite of more than 40 years of practical and academic work on integrated systems of management in fisheries (see Charles 2001 for a comprehensive overview of systems approaches to fisheries). For more than two decades, the promise of a more holistic and full spectrum treatment of fisheries systems - consisting not just of fish, fishermen, and managers, but also fishing communities, ecosystems, governance institutions, markets, social networks, and belief systems - has remained unfulfilled. The United Nations Sustainable Development Goals (SDGs), adopted in September 2015, demonstrate the overwhelming emphasis placed on the environment when considering the ocean and fisheries (UN 2015). The SDG goals, of which there are 17, cover a wide range of issues including health and well-being, poverty, decent work, and inequalities. SDG 14 is specific to the oceans and includes seven targets of which six are primarily concerned with conservation issues. Although the SDGs are meant to be implemented together, this has not prevented the consideration of oceans through SDG 14 in isolation from the broader social, economic, and institutional lens offered by the full suite of SDGs (see Lubchenco and Grorud-Colvert 2015 as an example).
Although these failures can be reasonably attributed to the challenges in integrating across a wide array of considerations, there are practical reasons to support a genuinely comprehensive and full spectrum approach to sustainability in fisheries. The current context of climate change, increasing environmental uncertainty due to anthropogenic activities, and stronger societal values related to conservation, coupled with widely held expectations for sustained economic growth and equitable treatment, places enormous pressures on fisheries managers to demonstrate to a wide range of interested parties that they are following sustainable practices. A narrow definition of sustainability that focuses on abundance of single species that are of economic interest fails to satisfy the concerns of environmental activists, indigenous rights-holders, fishing communities, and recreational and commercial fishers. It is in the interest of fisheries managers to adopt a broader and more fully realized approach to sustainability and, perhaps more importantly, it is vital that there be wide recognition and acceptance that adopting a more complete approach to sustainability is a priority within the management system.

Indicator-based frameworks are a tool that, if used appropriately, can support management in the progression toward sustainable fisheries. A framework with indicators consists of two main components: a structure that defines the categories of interest, for instance, habitat, or economic impacts, accompanied by a list of indicators, e.g., annual landings in tonnes of a particular fish species, that can be used to help evaluate what is occurring within a category. The framework itself can be a single level, with one or

${ }^{1}$ School of Resource \& Environmental Management, Simon Fraser University, Burnaby, BC, Canada, ${ }^{2}$ Uu-a-thluk (Fisheries), Nuu-chah-nulth Tribal Council, Port Alberni, BC, Canada, ${ }^{3}$ Institute for the Oceans and Fisheries, University of British Columbia, Vancouver, BC, Canada, ${ }^{4}$ Department of Anthropology, University of New Brunswick, Fredericton, NB, Canada, ${ }^{5}$ Ocean Frontier Institute, Environmental Policy Institute, Memorial University (Grenfell Campus), Corner Brook, NL, Canada 
more categories that each contains a set of indicators, or it can be a hierarchical structure that attempts to model the system with greater complexity. Indicators can be quantitative or qualitative, although many fisheries frameworks exclusively use quantitative indicators because they can easily be summarized and related to reference points using modeling and statistical analyses. The argument has been made that indicators must be nonsubjective and quantitative to match with targets that must be SMART: specific, measurable, achievable, realistic, and time-bounded (Cormier and Elliott 2017). Although the importance of qualitative measures has also been noted, especially given the limits of quantitative approaches (Shore 2008, Busch et al. 2012, Davis et al. 2012). Indicators can range from highly specific to very general and may or may not be linked to one another in an attempt to produce an aggregate assessment of sustainability within a system.

Sustainability frameworks have proliferated in academic and policy contexts since the second wave of environmentalism in the 1990s. In 2000, the United Nations (UN) Millennium Development Goals (MDG) were established (UN 2019). The MDGs link eight areas of interest (poverty, education, environment, etc.) with quantitative indicators as a way of measuring progress toward sustainable development on a global scale. The forestry sector pioneered the development of marketbased certification schemes for natural resource use (Maser and Smith 2001, Cashore et al. 2004). Within fisheries, the Food and Agriculture Organization (FAO) of the UN has devoted substantial resources to the development of sustainability frameworks and indicators (FAO 1999, 2003, 2009, 2010, 2011, Garcia et al. 2000, 2003, Tietze et al. 2001, Gréboval 2002). The interactive governance approach proposes an assessment framework that is question-driven and views fisheries systems through the lens of governability (Kooiman et al. 2005, Chuenpagdee et al. 2008, Bavinck and Kooiman 2013, Kooiman and Bavinck 2013). Market-oriented sustainability frameworks in the fisheries sector, such as the Marine Stewardship Council's Principles and Criteria for Sustainable Fishing, and competing initiatives have gained a higher profile in the past 20 years (see Leadbitter and Ward 2007, MSC 2011, Foley and Hébert 2013, Faught 2016, Foley and Havice 2016). In a few national jurisdictions, notably Australia, management agencies have developed and implemented comprehensive framework-based approaches to sustainable fisheries management (Chesson et al. 1999, Ward 2000, 2014, Fletcher 2006, Fletcher et al. 2002, 2003, 2005, 2010, Begg et al. 2014, Brooks et al. 2015, Triantafillos et al. 2014).

Canada, in spite of being an important fishing nation (FAO 2016) with a long tradition of fisheries science research (Ricker 1975, Hubbard et al. 2016), has lagged behind countries like Australia (see above) and the USA (Busch et al. 2003, Pollnac et al. 2006, Clay et al. 2014, Breslow et al. 2014) in the move toward comprehensive approaches to sustainability in fisheries management. Canada has committed in legislation to an ecosystem approach to fisheries (Oceans Act, S.C., 1996, c.31). Although ecosystem-based management (EBM) conceptually includes consideration of humans as a component of the larger ecosystem, critical human factors are frequently missed in the application of EBM (Arkema et al. 2006, Long et al. 2015) and the emphasis within EBM research has primarily been on ecological and oceanographic aspects (Ommer et al. 2012, Epstein et al. 2018). The federal fisheries management agency, Fisheries and Oceans Canada (DFO), released a "Sustainable Fisheries Framework" (SFF) in 2009 that is not a framework in the sense discussed above, but rather a collection of loosely connected policy and management documents dealing with topics such as the protection of benthic habitat, managing bycatch, decision making following the precautionary approach, and forage species (http://www.dfo-mpo.gc.ca/reports-rapports/regs/sff-cpd/overviewcadre-eng.htm). A recent (2015) "sustainability survey" based on the SFF focuses entirely on questions related to biological and ecological sustainability, which reflects the nature of the policy documents that comprise the DFO framework (http://www.dfompo.gc.ca/reports-rapports/regs/sff-cpd/survey-sondage/index-en. html). In a similar vein, the DFO and Canadian Coast Guard 2017-2020 Departmental Sustainable Development Strategy (FSDS; http://waves-vagues.dfo-mpo.gc.ca/Library/40749782.pdf) identifies "healthy coasts and oceans" as one of its goals. To accomplish this, there are continued efforts to implement the SFF and further policies on it. Although the FSDS states that it will work in accordance with the Federal Sustainable Development Act (Government of Canada 2008) to integrate environmental, social, and economic sustainability, the SFF remains focused on ecological and biological considerations. The sustainability survey and FSDS reinforce the impression that the SFF has limited value as a practical tool to comprehensively evaluate the sustainability of fisheries under the jurisdiction of DFO.

The Canadian Fisheries Research Network (CFRN) was a sixyear research network intended to move Canadian fisheries management closer to the goal of sustainability on a number of fronts. One of the major initiatives within the CFRN was Project 1.1, which focused the efforts of an interdisciplinary team of academic, industry, and government experts on the development of a comprehensive framework for evaluating fisheries in Canada (Stephenson et al. 2018, 2019). As an offshoot of that effort, a subgroup within the CFRN developed a framework for use in several of the case studies that were being undertaken by the network. Intended to support the identification of fisheries management objectives while linking objectives directly to indicators, the evaluation framework for sustainable fisheries (hereinafter the sustainability indicator framework), as it was named, went through several iterations that resulted in different versions being developed (for one such iteration see Stephenson et al. 2019). The focus of this paper is on the development of an iteration of the sustainability indicator framework that supports a comprehensive, full-spectrum evaluation across three domains: governance, ecological, and social and economic. The framework is intended to be widely applicable to fisheries in Canada as well as in other jurisdictions that have a similar governance structure, i.e., established and functioning democratic institutions, and high level of institutional capacity, e.g., for data collection, science, management, and enforcement. Descriptors and indicators for each element were also developed to provide guidance in the application of the sustainability indicator framework, in particular to support practitioners to assess multiple domains, even those outside their areas of individual expertise.

\section{THE SUSTAINABILITY INDICATOR FRAMEWORK DEVELOPMENT PROCESS}

The CFRN was formed in 2010 with the purpose of bringing together industry, academics, and government to collaborate on priority research issues contributing to ecological sustainability, 
viability, and improved management of Canadian fisheries. With federal funding through the Government of Canada's Natural Sciences and Engineering Research Council, the majority of projects related to the natural sciences. The major exception was Project 1.1 which was tasked with investigating the nature of sustainability in fisheries and the range of objectives driving fisheries management in Canada. In a departure from the usual practice in natural science research networks in Canada, the CFRN Project 1.1 research team included several social scientists working on fisheries in Canada who represented a range of disciplines: fisheries economics, maritime anthropology, sociology, management, and marine governance. Working closely with industry and government representatives, the academics in Project 1.1 adopted an evaluation framework approach to the question of fisheries sustainability.

At the same time, a number of research projects within the network included the assessment of outcomes through structured decision-making approaches, e.g., management strategy evaluation (MSE), and were challenged with the identification of performance metrics as indicators to assess a range of objectives that extended beyond those typical of most MSE applications. In the interests of drawing from a common pool of indicators grounded in a theoretically robust framework that would also support interfishery and interproject comparisons, a group of researchers adapted the Project 1.1 evaluation framework to more closely correspond to the requirements of their individual projects. This led to the creation of a comprehensive, tiered sustainability indicator framework with candidate indicators that became a foundational element for a number of research projects within the network.

\section{Domains, dimensions, and elements}

The sustainability indicator framework uses a three-level hierarchical structure: (1) domains, (2) dimensions, and (3) elements. Domains refer to the three primary, high-level fields of study and interest (governance, ecological, and social and economic). Dimensions are the broad subject headings within each domain that are used to organize conceptually similar elements, which comprise the third level of the hierarchy. Domains, dimensions, and elements provide an organizing framework and do not denote inherent or assumed values or goals. The term element was chosen to replace goal, which was used in the first iteration of the sustainability indicator framework because the directional quality associated with the concept of a goal was problematic since it prescribed a desirable end state. The purpose of each level in the hierarchy is to identify, with increasing specificity, the subject matter that should be evaluated in relation to fisheries sustainability. Goals and objectives exist outside of the hierarchy, and are addressed later in the discussion of indicator selection. The hierarchical structure within each of the three domains is represented in the diagrams that follow (Figs. 1, 2, and 3).

The components of the sustainability indicator framework were identified through consideration of hundreds of models and theories that underlie different elements, ranging from carrying capacity of freshwater lakes to the degree to which there are mechanisms in place to recognize and allow for conflict and conflict resolution (for a case study on the latter see Parlee and Wiber 2018). As a result, we conceptualize the sustainability indicator framework at the domain and dimension level as atheoretical and descriptive, with no single overarching theory that connects the domains and dimensions or relates the elements across domains to one another.

\section{Governance domain}

We hypothesize an underlying logic for the governance domain (Fig. 1). Mindful of critiques that have been made of the term governance (Offe 2009), we nevertheless chose that label to communicate that this domain is broader than institutions. The first dimension, institutional arrangements, provides the structural support for the next dimension, decision making, by defining the purpose and scope of the institution, the rules that structure interactions in an institutional setting, and the resources available to support these interactions. The decision-making dimension is about the process of making decisions, and invokes core principles of good governance: collaboration, transparency, inclusivity, predictability, flexibility, and accountability. The output of these processes, the decisions, can be evaluated individually and as a whole in terms of their effectiveness and their legitimacy. By effectiveness we mean the degree to which decisions help to carry out the mandate, the purpose of the institution. Legitimacy we define as the willingness of those affected by the governance institution to accept and abide by the decisions it produces, whether or not they are in agreement.

Fig. 1. Governance domain.

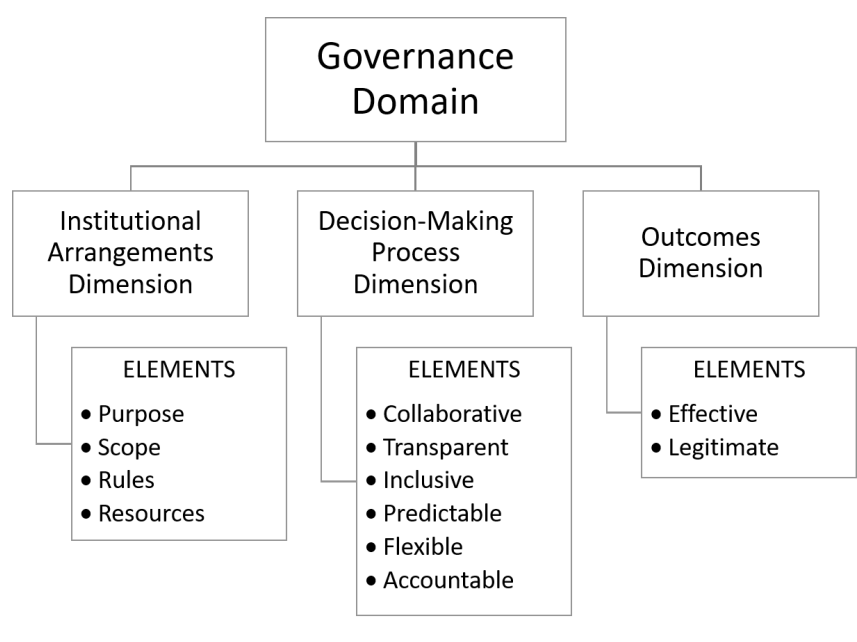

In this manner, the elements within each dimension function as the foundation for the next dimension and the next sequence of elements (see Table 1 for short definitions of the elements within each dimension). For instance, without financial support (part of the resources element), collaboration by participants in decision making is exceedingly difficult to achieve. Without goals and objectives (part of the purpose and rules elements), accountability is impossible to assess. Without open and informed decision making (part of the transparency element), the legitimacy of the governance institutions is thrown into question (for an example of how these criteria can be applied see Parlee 2016, Parlee and Wiber 2018) 
Table 1. Elements in the governance domain.

\begin{tabular}{ll}
\hline \hline Dimension & Element \\
\hline Institutional & Purpose: goals and objectives of the governance structure and processes \\
Arrangements & Scope: participants, geographic and temporal scale and boundaries, issues involved \\
& Rules: laws, regulations, and policies as well as de facto rules that structure the governance process \\
& Resources: human, technical, and financial resources available to support governance \\
Decision-Making Process & Collaborative: collaborative relationships within and between participants in decision making \\
& Transparent: open and informed policies, procedures, decisions, and supporting documentation \\
& Inclusive: processes that support participation by all parties with a legitimate interest \\
& Predictable: predictable and consistent decision-making procedures that are not changed without adequate consultation or \\
& justification \\
& Flexible: flexible and responsive processes that can be adapted to changing circumstances \\
& Accountable: explicit mechanisms of responsibility for actions, decisions, and outcomes \\
& Effective: processes that produce the intended outcomes and can be seen to do so \\
Outcomes & Legitimate: processes and outcomes that are generally seen as fair and reasonable regardless of self-interest \\
\hline
\end{tabular}

\section{Ecological domain}

The ecological domain (Fig. 2) also has an internal logic to it. In this case, the dimensions reflect a sequence of expanding scale and complexity. The first dimension, population and species, focuses on single species processes, which is the traditional focus of fisheries management. This dimension includes the elements that are typically used to determine sustainable harvesting levels for intra-specific groups, e.g., stocks, populations, and contingents, as prescribed by classic fisheries science and management literature (e.g., Beverton and Holt 1957, Hilborn and Walters 1992). The habitat and environment dimension was designed to encompass all physical biotic and abiotic structures of the ecosystem that interact with the intra-specific groups of interest within the first dimension. The third dimension, ecosystem structure and functionality, is intended to capture all the ecosystem interactions across species and within habitats. The ecosystem dimension is the integrative dimension within the ecological domain, akin to the ecosystem approach that informs DFO management (Jamieson et al. 2001, Gavaris 2009). The elements and indicators within this dimension (see Table 2 for short definitions of the elements) rely on syntheses of the information gathered across earlier elements within the domain.

Fig. 2. The ecological domain.

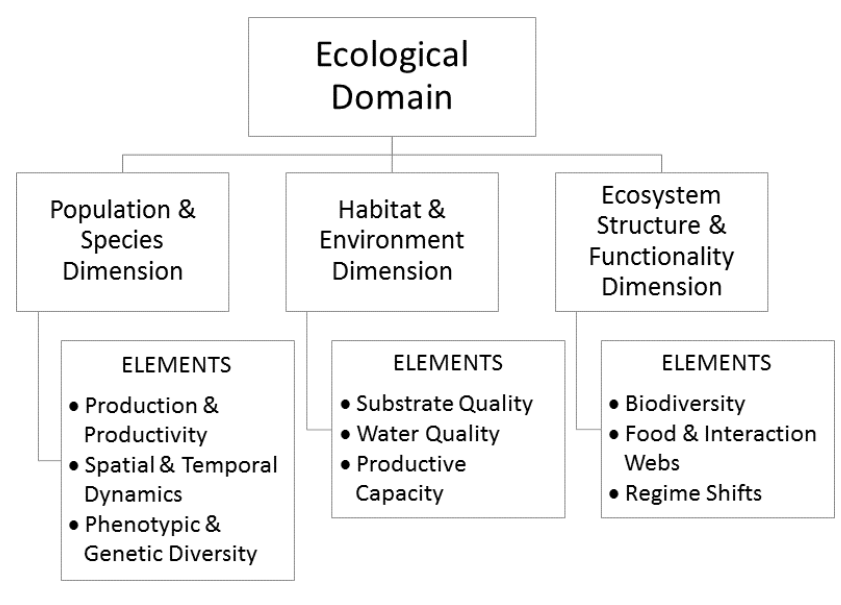

\section{Social and economic domain}

Unlike with the other two domains, the dimensions within the social and economic domain (Fig. 3) represent relatively distinct and discrete aspects of the domain. Although there is a reasonable case to be made to treat social and economic issues as separate domains, a deliberate approach was taken to combine social and economic aspects based on the argument that economics and the economy as a whole fit within a larger social realm (Polanyi 1957, Granovetter 1985). Not all relationships are market ones; nor should they be. The frequent claim that economics speaks for society, and that efficiency is conducive to social welfare in general, is a political and ideological assertion, not a law of nature. Efficiency as a concept has been particularly problematic in fisheries, being widely assumed to be a goal in itself, and in direct conflict with equity and employment through a false choice arising from a misapplication of the concept (Bromley 2009). We thus treat the social and economic as a joint system and constrained the classical emphasis on efficiency by adding in the concepts of viability, sustainability, and equity in the economics and finances dimension (see Table 3 for short definitions of the elements in this dimension). Furthermore, as previously mentioned when introducing the domains, dimensions, and elements structure, the framework provides an organizing structure to help identify goals and objectives. It does not provide or assume goals or objectives, nor does it replace or otherwise eliminate the important step of identifying fisheries appropriate goals and objectives when conducting an evaluation. The dimensions and elements should not be assumed to represent goals or objectives and their application within an evaluation should be considered with respect to the goals and objectives of the fishery under consideration.

The health and well-being dimension reflects a recent development in theory on fisheries that starts with the binary distinction between material and subjective well-being common in the economics literature (Helliwell and Barrington-Leigh 2010) and adds a third component, relational well-being (Weeratunge et al. 2014).

The social justice dimension is a seldom mentioned addition to sustainability frameworks. The purpose is to explicitly account for cross-cutting issues that are important in fisheries but often neglected or difficult to address in management contexts 
Table 2. Elements in the ecological domain.

\begin{tabular}{ll}
\hline \hline Dimension & Element \\
\hline Population and Species & $\begin{array}{l}\text { Production and Productivity: population size and the rate of change } \\
\text { Spatial and Temporal Dynamics: geographic patterns, migrations routes, and distribution of population and species } \\
\text { Phenotypic and Genetic Diversity: differences in morphology of individuals due to environmental and genetic variation } \\
\text { Substrate Quality: condition of biotic and abiotic structures used by aquatic organisms during their life cycle, including extent, } \\
\text { Habitat and Environment } \\
\text { Wability, and quality }\end{array}$ \\
& $\begin{array}{l}\text { Productive Capacity: the natural equilibrium capability of habitats to produce healthy fish stocks and aquatic organisms on } \\
\text { which fish depend } \\
\text { Biodiversity: number and variety of organisms within a particular ecosystem }\end{array}$ \\
Funcosystem Structure and & $\begin{array}{l}\text { Food and Interaction Webs: energy flows and interactions between trophic levels and populations in an ecosystem } \\
\text { Regime Shifts: persistent changes in the structure and function of an ecosystem }\end{array}$ \\
\hline
\end{tabular}

Table 3. Elements in the social and economic domain.

\begin{tabular}{|c|c|}
\hline Dimension & Element \\
\hline Health and Well-being & $\begin{array}{l}\text { Material Well-being: basic needs, physical welfare, and standards of living } \\
\text { Relational Well-being: relations of love and care, networks of support and obligation, social, political, and cultural identities } \\
\text { Subjective Well-being: personal perception of individual and collective health and well-being, sense of agency and self- } \\
\text { efficacy }\end{array}$ \\
\hline Economics and Finance & $\begin{array}{l}\text { Economic Efficiency: value obtained from the resource relative to costs, waste, and negative externalities } \\
\text { Financial Viability: financial health of enterprises and other institutions involved in the fishery } \\
\text { Economic and Financial Sustainability: sustainability of profits at all stages of the value chain } \\
\text { Equity: fairness of how costs and benefits of the fishery are distributed amongst participants }\end{array}$ \\
\hline Social Justice & $\begin{array}{l}\text { Poverty and Livelihoods: consideration of the interests of the poor and fishing livelihoods in the management of the resource } \\
\text { Women and Gender: consideration of the interests of women and gender issues in the management of the resource } \\
\text { Fishing Communities: consideration of the interests of fishing communities in the management of the resource } \\
\text { Indigenous Peoples: consideration of the interests of indigenous peoples in the management of the resource } \\
\text { Future Generations: consideration of the interests of future generations in the management of the resource }\end{array}$ \\
\hline
\end{tabular}

Fig. 3. Social and economic domain.

\begin{tabular}{|c|c|c|}
\hline & $\begin{array}{c}\text { Social \& Economic } \\
\text { Domain }\end{array}$ & \\
\hline $\begin{array}{l}\text { Health \& Well-being } \\
\text { Dimension }\end{array}$ & $\begin{array}{c}\text { Economics \& } \\
\text { Finance Dimension }\end{array}$ & $\begin{array}{l}\text { Social Justice } \\
\text { Dimension }\end{array}$ \\
\hline $\begin{array}{l}\text { ELEMENTS } \\
\text { - Material Well-being } \\
\text { - Relational } \\
\text { Well-being } \\
\text { - Subjective } \\
\text { Well-being }\end{array}$ & $\begin{array}{l}\text { ELEMENTS } \\
\text { - Economic Efficiency } \\
\text { - Financial Viability } \\
\text { - Economic \& } \\
\text { Financial } \\
\text { Sustainability } \\
\text { - Equity }\end{array}$ & $\begin{array}{l}\text { ELEMENTS } \\
\text { - Poverty \& } \\
\text { Livelihoods } \\
\text { - Women \& Gender } \\
\text { - Fishing } \\
\text { Communities } \\
\text { - Indigenous Peoples } \\
\text { - Future Generations }\end{array}$ \\
\hline
\end{tabular}

(Coulthard et al. 2011). The underlying logic is that there are groups that are particularly vulnerable to ecosystem change, social and economic pressures, and management actions, but receive less attention within conventional management frameworks. The adoption of the social justice dimension resolved, or at least provided a way to deal with, one of the major tensions in the process of developing the sustainability indicator framework, which was how to give prominence to particular perspectives without creating an impossibly cumbersome framework structure.

\section{Objectives, indicators, and attributes}

Another critical motivation that drove the development of the sustainability indicator framework discussed here was the need for a comprehensive and systematic approach to identifying objectives for fisheries management in specific contexts. The approach adopted by the larger Project 1.1 group in the CFRN was to identify objectives in a top down manner, guided by Canadian and international legal, policy, and regulatory documents. As we worked through the process of identifying objectives in individual case studies, we posited a counterview that goals and objectives should be fishery specific and defined by the participants in the fishery: managers, stakeholders, rightsholders, and other interested parties. Goal and objective identification is a critical step in conducting an evaluation, whose purpose is to define the desired end state against which the system is to be evaluated. The sustainability indicator framework provides a structure to facilitate the process of identifying goals and objectives through a bottom-up approach. With that in mind, we put a strong emphasis on designing a sustainability indicator framework that would be reasonably easy to explain to a wide range of interested groups, avoiding overly technical language where possible and including short definitions of all the elements (Tables 1, 2, and 3). Two of the authors, Edwards and Hawkshaw, tested the sustainability indicator framework as a tool for identifying objectives in workshops with fishermen and refined it based on the feedback received. 
Table 4. Example indicators.

\begin{tabular}{|c|c|}
\hline Location in Hierarchy & Example Indicators \\
\hline $\begin{array}{l}\text { Domain: Governance } \\
\text { Dimension: Institutional Arrangements } \\
\text { Element: Collaborative }\end{array}$ & $\begin{array}{l}\text { Evidence from [Qualitative Methods] of [Stakeholder Group] and [Human Population] perception } \\
\text { of collaboration by [Collaboration Type]; } \\
\text { Degree to which [Collaboration Criteria] exist; } \\
\text { [Quantification] of [Collaboration Criteria]; } \\
\text { [Quantification] of [Stakeholder Group] participation in [General Management Activity] and/or } \\
\text { [Fisheries Management Activity]; }\end{array}$ \\
\hline $\begin{array}{l}\text { Domain: Ecological } \\
\text { Dimension: Population \& Species } \\
\text { Element: Production \& Productivity }\end{array}$ & $\begin{array}{l}\text { Quantification of [Resource Demographic Category] within a [Resource Geographic Region]; } \\
\text { [Quantification] of productivity of [Resource Demographic Category] within a [Resource } \\
\text { Geographic Region]; } \\
\text { [Recruitment Dynamics] description for [Resource Demographic Category]; } \\
\text { [Quantification] of [Mortality]; } \\
\text { [Quantification] of escapement and relationship to [Recruitment Dynamics] and [Reference Points]; }\end{array}$ \\
\hline $\begin{array}{l}\text { Domain: Social and Economic } \\
\text { Dimension: Economics and Finance } \\
\text { Element: Equity }\end{array}$ & $\begin{array}{l}\text { [Income Disparity Metric] in [Human Geographic Region]; } \\
\text { Distribution of [Value Type] by [Value Chain Element]; } \\
\text { Distribution of [Value Type] by [Operator Type]; }\end{array}$ \\
\hline
\end{tabular}

At the same time, we were concerned that the selection of indicators needs to be directly tied to the identification of objectives. It quickly became obvious that without the specific objectives, there is an enormous range of potential indicators for each element. As soon as you begin to consider questions of scale (spatial, temporal, procedural, organizational and so on) a single indicator like fish landings turns out to be a list of dozens of potential individual indicators. For most indicators, there are a number of different ways in which the indicator can vary (e.g., by scale, by function, by type). We adopted a systematic approach to recognize the ways in which the indicators can vary while containing the quantity of indicators being developed. For example, if an indicator about fish landings is being applied to a multisector fishery it needs to be repeated to reflect the different gear types. This was achieved much more efficiently by replacing each reference to the gear type with a gear-type variable that could hold different values: hook and line, troll, dive, purse seine, and so on. We refer to these variable values as attributes.

The indicator-attribute structure should be implemented for indicators in all domains (see the examples in Tables 4 and 5 below). Rather than dictating specific indicators to be used, we provide example indicators that contain attributes that can be defined within a particular fishery context. The indicators in the sustainability indicator framework are formulas that can be used to produce fishery-specific indicators. The indicator-attribute approach has a specific syntax and the attributes are variables within this syntax. The flexibility and nonprescriptive nature of this approach means that fishery appropriate indicators can then be established in order to reflect the specific objectives of a fishery. These two aspects of the sustainability indicator framework, the comprehensive structure and the indicator-attribute format, are thus linked in a way that enforces comprehensive and routine methods for identifying objectives and relating these to specific indicators.

\section{POTENTIAL USES OF THE SUSTAINABILITY INDICATOR FRAMEWORK}

Although report cards and summary rating systems are a commonly used tool in fisheries evaluation, justified as a means to make sustainability assessments more accessible (Pitcher and
Preikshot 2001), the rigor of the techniques used and veracity and value of outcomes are questionable, particularly when dealing with system level attributes as complex as sustainability (Jacquet and Pauly 2007, Froese and Proelss 2012, Foley and McCay 2014). Therefore, we argue that the sustainability indicator framework should not be used to derive a final number or letter, a quantitative rating, or a grade as in a report card.

Alternatively, we suggest that the sustainability indicator framework as described in this paper can assist users to monitor, assess, and understand ecosystem status, the impacts of human activities, and the effectiveness of management measures in achieving management objectives. It can be used as a facilitation tool and organizing structure to identify and define management objectives. It can also be applied to discuss and debate inevitable, yet often only implicitly addressed issues such as trade-offs, cumulative impacts, the governance of governance (Kooiman and Jentoft 2009), and the interaction among policies (for interaction among policies see Murray et al. 2010, Barnett 2018, Carruthers et al. 2019). The sustainability indicator framework does not tell managers what the sum of all activities will be or how to make trade-offs. It does however, integrate many different criteria into a single mental model and can encourage management to explicitly think about their choices and the consequences those choices might have. This sustainability indicator framework was created to contextualize these issues and empower managers to examine their decisions and assess whether they are working.

The sustainability indicator framework is also a research tool that could, potentially, find a wide range of uses. Within government, indicators developed through the sustainability indicator framework might be incorporated into integrated fisheries management plans (IMFPs; for a theoretical application see Barnett 2018). It could be used to complement and supplement ecosystem-based management approaches, particularly in ensuring a comprehensive and integrative approach that is inclusive of social, economic, and governance issues related to ecosystem management. It could also be used by stakeholders, e.g., management advisory committees, to monitor and assess marine protected areas, national marine 
Table 5. Example attributes.

\begin{tabular}{|c|c|}
\hline Attribute & Examples of Attribute \\
\hline Collaboration Criteria & $\begin{array}{l}\text { power-sharing; information-sharing; shared rule-making; multiparty agreements signed and/or renewed; } \\
\text { multiparty management plans; mechanisms for conflict and conflict resolution. }\end{array}$ \\
\hline Collaboration Type & public-private partnerships; private-social partnerships; comanagement \\
\hline Fisheries Management Activity & $\begin{array}{l}\text { monitoring; enforcement; stock assessment; research; habitat monitoring; habitat protection; habitat } \\
\text { restoration; habitat enhancement; harvest planning; harvest management; evaluation }\end{array}$ \\
\hline General Management Activity & $\begin{array}{l}\text { regional advisory processes; government budget allocation processes; management agency administration } \\
\text { processes; science advisory processes; management agency hiring processes }\end{array}$ \\
\hline Human Geographic Region & country; province; region; community; First Nation territory \\
\hline Human Population & general human population; fisheries participants; indigenous peoples; youth; women; men; coastal communities \\
\hline Income Disparity Metric & Gini coefficient; ratio of highest wage to average wage; proportion below poverty line \\
\hline Index of Abundance & catch per unit effort; weight per unit effort; survey estimates; stock assessment biomass/abundance estimates \\
\hline Mortality & Fishing mortality; target fishing mortality; natural mortality; incidental mortality \\
\hline Operator Type & $\begin{array}{l}\text { processor with fisheries access rights; nonparticipating access owner (investor); owner-operator; active } \\
\text { fishermen without ownership access }\end{array}$ \\
\hline Qualitative Methods & survey; focus group; interviews; public hearing; public inquiry; ethnography; legal proceedings; media articles \\
\hline Quantification & proportion; number; frequency; total area; total volume; presence/absence; ratio \\
\hline Recruitment Dynamics & shape of recruitment curve; compensation or depensation; changes in average recruitment \\
\hline Reference Points & limit reference points; upper reference points; target reference points \\
\hline Resource Demographic Category & species; population; stock; size; sex; age; class \\
\hline Resource Geographic Region & $\begin{array}{l}\text { province; country; exclusive economic zone; region; management area; marine area; river system; lake; } \\
\text { watershed }\end{array}$ \\
\hline Stakeholder Group & $\begin{array}{l}\text { indigenous communities; processors; trade unions; fishermen's associations; industry associations; recreational } \\
\text { users; regional government; community groups; environmental interests; provincial government }\end{array}$ \\
\hline Value Chain Element & producer; processor; wholesaler; retailer; consumer; investor \\
\hline Value Type & landed value; export value; wholesale value; retail value \\
\hline
\end{tabular}

conservation areas, and other similar management arrangements. An essential part of management effectiveness is the evaluation of outcomes of a specific protected area against specific objectives. This requires that specific, context-relevant objectives be identified, and then that appropriate indicators for various objectives be monitored to determine whether those objectives are being met (DFO 2005). In time, this could help to develop a common vocabulary amongst stakeholders that would support advisory and consultation processes (Brand and Jax 2007). Industry might find the sustainability indicator framework beneficial in engaging with policies and articulating the types of participatory processes they envision. For communities and regions where fishing is important, a potentially valuable function of the sustainability indicator framework lies in how it can be used to structure dialogue around the components of a fishery that should be monitored at the local level.

Notwithstanding efforts to develop a sustainability indicator framework that was generally applicable to a wide range of situations, it is important to point out that the sustainability indicator framework is only suitable for application in democracies with advanced economies and established fisheries management regimes. It is primarily designed for commercial fisheries, although it could be adapted to noncommercial contexts such as recreational, subsistence, or indigenous fisheries, or even beyond fisheries to other marine sectors such as aquaculture and potentially even to terrestrial systems. The governance section in particular precludes the use of the sustainability indicator framework in countries without the basic structures of democracy: periodic free elections, universal suffrage or something close to that, an independent judiciary, freedom of speech, conscience, association, assembly, and so on. Elements in the sustainability indicator framework such as accountability, transparency, or legitimacy may be challenging to realize in democracies; they are likely unattainable in authoritarian regimes or dictatorships.

The framework should be adapted, as necessary, to ensure an appropriate fit for the fishery and the intended use of the framework. The first step in using the sustainability indicator framework should be to identify the goals and objectives for the fishery, followed by a consideration of the purpose for using the framework and then the adaptation of the framework to meet the purpose. The higher level categories of domains, dimensions, and elements are meant to be applicable across a wide range of contexts. However, the framework is not static and is expected to evolve over time and with use. Adaptation can extend beyond the selection of fishery-appropriate indicators and attributes to also include adjustments to the structure. Although the framework is meant to be adapted, particularly at the indicator level but potentially also within the higher level category structures, it is not meant to be used selectively. A full-spectrum approach requires integration across all domains and domain components, including the social and governance aspects that are often underrepresented or ignored (Cuthill 2010, Boström 2012). An evaluation using the framework should always include the full spectrum of domains, dimensions, and elements, even where no data are available to report on the outcome. The absence of data is itself information to be considered and can help ensure that data-deficiency issues are brought to light. The refocusing or removal of dimensions or elements should be well considered and justified based on the context of the fishery system, and never due to data, time, or similar logistical limitations.

\section{CONCLUSION}

In this paper we provided a detailed account of the work undertaken to develop a comprehensive, full spectrum, sustainability indicator framework. The sustainability indicator 
framework is assembled in a hierarchical subject matter structure, which comprises domains, dimensions, and elements. For each domain, instead of prescribing specific indicators, a procedure for generating fisheries specific indicators with the insertion of attributes is described. The dimensions go beyond the narrow scope of biological and economic considerations to include social, cultural, institutional, and ethical dimensions of the fisheries. And, for each element a descriptor is given. This approach allows users of the sustainability indicator framework to do three things: (1) comprehensively and routinely identify relevant objectives and indicators; (2) systematically address each of the three domains without prioritizing any one domain over another; and (3) integrate multiple domains outside their areas of expertise, into a specific management program, project, or scheme. Finally, we illustrate that the sustainability indicator framework is both specific and flexible enough to be used across a range of fisheries management contexts.

Responses to this article can be read online at: http://www.ecologyandsociety.org/issues/responses. php/11242

\section{Acknowledgments:}

This research was supported by the Canadian Fisheries Research Network, funded by the Natural Sciences and Engineering Research Council of Canada (NET GP 389436-09). C. Parlee was also funded by a Social Sciences and Humanities Research Council of Canada Doctoral Award (Ref \#752-2013-1817). We would like to thank a group of researchers that contributed to early development of the framework (listed in last name alphabetical order ): ): Allan Debertin, Aaron Greenberg, Andrea Haas, Mike Hawkshaw, Robin Messenger and Dan Mombourquette. We also would like to thank Dr. Melanie Wiber and Dr. Robert Stephenson for their support and feedback throughout the writing process.

\section{LITERATURE CITED}

Arkema, K. K., S. C. Abramson, and B. M. Dewsbury. 2006. Marine ecosystem-based management: from characterization to implementation. Frontiers in Ecology and the Environment 4 (10):525-532. https://doi.org/10.1890/1540-9295(2006)4[525:MEMFCT] 2.0.CO;2

Barnett, A. J. 2018. Recommendations for full-spectrum sustainability in Canadian lobster integrated management plans based on a socioeconomic analysis of Barrington, Nova Scotia. Ecology and Society 23(1):36. https://doi.org/10.5751/ES-09981-230136

Bavinck, M., and J. Kooiman. 2013. Applying the governability concept in fisheries: explorations from South Asia. Pages 131-153 in M. Bavinck, R. Chuenpagdee, S. Jentoft, and J. Kooiman, editors. Governability of fisheries and aquaculture: theory and applications. Springer, Dordrecht, The Netherlands. https://doi. org/10.1007/978-94-007-6107-0_8

Begg, G. A., K. J. Brooks, R. L. Stephenson, and S. R. Sloan. 2014. Practical implementation of social and economic elements in ecosystem based fisheries management and integrated fisheries management frameworks. Report of a workshop, 24-25 March 2014.
South Australian Research and Development Institute, Adelaide, Australia. [online] URL: http://frdc.com.au/Archived-Reports/ FRDC\%20Projects/2008-328.18-DLD.pdf

Beverton, R. J. H, and S. J. Holt. 1957. On the dynamics of exploited fish populations. UK Ministry of Agriculture and Fisheries, London, UK.

Boström, M. 2012. A missing pillar? Challenges in theorizing and practicing social sustainability: introduction to the special issue. Sustainability: Science, Practice and Policy 8(1):3-14. https://doi. org/10.1080/15487733.2012.11908080

Brand, F. S., and K. Jax. 2007. Focusing the meaning(s) of resilience: resilience as a descriptive concept and a boundary object. Ecology and Society 12(1):23. https://doi.org/10.5751/ ES-02029-120123

Breslow, S., D. Holland, P. Levin, K. Norman, M. Poe, C. Thomson, R. Barnea, P. Dalton, N. Dolsak, C. Greene, K. Hoelting, S. Kasperski, R. Kosaka, D. Ladd, A. Mamula, S. Miller, B. Sojka, C. Speir, S. Steinbeck, and N. Tolimieri. 2014. Human dimensions of the CCIEA: a summary of concepts, methods, indicators, and assessments. Pages 1-37 in C. J. Harvey, N. Garfield, E. L. Hazen, and G. D. Williams, editors. The California current integrated ecosystem assessment: Phase III Report. National Oceanic and Atmospheric Administration: Southwest Fisheries Science Centre, La Jolla, California, USA. [online] URL: https://swfsc.noaa.gov/publications/CR/2014/2014Breslow. pdf

Bromley, D. W. 2009. Abdicating responsibility: the deceits of fisheries policy. Fisheries 34(6):280-290. https://doi. org/10.1577/1548-8446-34.6.280

Brooks, K., J. Schirmer, S. Pascoe, L. Triantafillos, E. Jebreen, T. Cannard, and C. M. Dichmont. 2015. Selecting and assessing social objectives for Australian fisheries management. Marine Policy 53:111-122. https://doi.org/10.1016/j.marpol.2014.11.023

Busch, M., A. La Notte, V. Laporte, and M. Erhard. 2012. Potentials of quantitative and qualitative approaches to assessing ecosystem services. Ecological Indicators 21:89-103. https://doi. org/10.1016/j.ecolind.2011.11.010

Busch, W.-D. N., B. L. Brown, and G. F. Mayer, editors. 2003. Strategic guidance for implementing an ecosystem-based approach to fisheries management. NOAA, Silver Spring, Maryland, USA.

Carruthers, E. H., C. E. Parlee, R. Keenan, and P. Foley. 2019. Onshore benefits from fishing: tracking value from the northern shrimp fishery to communities in Newfoundland and Labrador. Marine Policy 103:130-137. https://doi.org/10.1016/j.marpol.2019.02.034

Cashore, B. W., G. Auld, and D. Newsom. 2004. Governing through markets: forest certification and the emergence of non-state authority. Yale University Press, New Haven, Connecticut, USA.

Charles, A. T. 2001. Sustainable fishery systems. Blackwell Science, Malden, Massachusetts, USA. https://doi. org/10.1002/9780470698785

Chesson, J., H. Clayton, and B. Whitworth. 1999. Evaluation of fisheries-management systems with respect to sustainable development. ICES Journal of Marine Science 56(6):980-984. https://doi.org/10.1006/jmsc.1999.0531 
Chuenpagdee, R., J. Kooiman, and R. Pullin. 2008. Assessing governability in capture fisheries, aquaculture and coastal zones. Journal of Transdisciplinary Environmental Studies 7(1):1-20.

Clay, P. M., A. Kitts, and P. Pinto da Silva. 2014. Measuring the social and economic performance of catch share programs: definition of metrics and application to the U.S. Northeast Region groundfish fishery. Marine Policy 44:27-36. https://doi. org/10.1016/j.marpol.2013.08.009

Cormier, R., and M. Elliott. 2017. SMART marine goals, targets and management - Is SDG 14 operational or aspirational, is 'life below water' sinking or swimming? Marine Pollution Bulletin 123 (1-2):28-33. https://doi.org/10.1016/j.marpolbul.2017.07.060

Coulthard, S., D. Johnson, and J. A. McGregor. 2011. Poverty, sustainability and human wellbeing: a social wellbeing approach to the global fisheries crisis. Global Environmental Change 21 (2):453-463. https://doi.org/10.1016/j.gloenvcha.2011.01.003

Cuthill, M. 2010. Strengthening the 'social' in sustainable development: developing a conceptual framework for social sustainability in a rapid urban growth region in Australia. Sustainable Development 18(6):362-373. https://doi.org/10.1002/ $\underline{\text { sd.397 }}$

Davis, K. E., A. Fisher. B. Kingsbury, and S. E. Merry. 2012. Governance by indicators: global power through quantification of rankings. Oxford University Press, Oxford, UK. https://doi. org/10.1093/acprof:oso/9780199658244.001.0001

Epstein, G., E. Andrews, D. Armitage, P. Foley, J. Pittman, and R. Brushett. 2018. Human dimensions of ecosystem-based management: lessons in managing trade-offs from the northern shrimp fishery in Northern Peninsula, Newfoundland. Marine Policy 97:10-17. https://doi.org/10.1016/j.marpol.2018.08.018

Fisheries and Oceans Canada (DFO). 2005. Canada's Federal Marine Protected Areas Strategy. Communications Branch Fisheries and Oceans Canada, Ottawa, Ontario, Canada. [online] URL: https://waves-vagues.dfo-mpo.gc.ca/Library/315822e.pdf

Fletcher, W. J. 2006. Frameworks for managing marine resources in Australia through ecosystem approaches: Do they fit together and are they useful? Bulletin of Marine Science 78(3):691-704.

Fletcher, W. J., J. Chesson, M. Fisher, K. Sainsbury, T. J. Hundloe, T. Smith, and B. Whitworth. 2002. National ESD reporting framework for Australian fisheries: the "how to" guide for wild capture fisheries. Fisheries Research and Development Corporation, Canberra, Australia.

Fletcher, W. J., J. Chesson, K. Sainsbury, M. Fisher, T. Hundloe, T. Smith, and B. Whitworth. 2003. National application of sustainability indicators for Australian fisheries. Fisheries Research \& Development Corporation, Canberra, Australia.

Fletcher, W. J., J. Chesson, K. J. Sainsbury, T. J. Hundloe, and M. Fisher. 2005. A flexible and practical framework for reporting on ecologically sustainable development for wild capture fisheries. Fisheries Research 71(2):175-183. https://doi.org/10.1016/j. fishres.2004.08.030

Fletcher, W. J., J. Shaw, S. J. Metcalf, and D. J. Gaughan. 2010. An ecosystem based fisheries management framework: the efficient, regional-level planning tool for management agencies.
Marine Policy 34(6):1226-1238. https://doi.org/10.1016/j. marpol.2010.04.007

Foley. P., and E. Havice. 2016. The rise of territorial ecocertification: new politics of transnational sustainability governance in the fishery sector. Geoforum 69:24-33. https://doi. org/10.1016/j.geoforum.2015.11.015

Foley, P., and K. Hébert. 2013. Alternative regimes of transnational environmental certification: governance, marketization, and place in Alaska's salmon fisheries. Environment and Planning A 45:2734-2751. https://doi.org/10.1068/a45202

Foley, P., and B. McCay. 2014. Certifying the commons: ecocertification, privatization, and collective action. Ecology and Society 19(2):28. https://doi.org/10.5751/ES-06459-190228

Foley, P., D. A. Okyere, and C. Mather. 2018. Alternative environmentalities: recasting the assessment of Canada's first Marine Stewardship Council-certified fishery in social terms. Ecology and Society 23(3):37. https://doi.org/10.5751/es-10382-230337

Food and Agriculture Organization of the United Nations (FAO). 1999. Indicators for sustainable development of marine capture fisheries. FAO, Rome, Italy.

Food and Agriculture Organization of the United Nations (FAO). 2003. The ecosystem approach to fisheries. FAO, Rome, Italy.

Food and Agriculture Organization of the United Nations (FAO). 2009. The ecosystem approach to fisheries 2.2 The human dimensions of the ecosystem approach to fisheries. FAO, Rome, Italy.

Food and Agriculture Organization of the United Nations (FAO). 2010. Expert workshop on the development and use of indicators for an ecosystem approach to fisheries. Rome, 20-24 April 2009. FAO EAF-Nansen Project Report. No 7. FAO, Rome, Italy. [online] URL: http://www.fao.org/3/am429e/am429e.pdf

Food and Agriculture Organization of the United Nations (FAO). 2011. Report of the expert consultation to develop an FAO evaluation framework to assess the conformity of public and private ecolabelling schemes with the FAO guidelines for the ecolabelling of fish and fishery products from marine capture fisheries. Rome, 24-26 November 2010. FAO Fisheries and Aquaculture Report. No. 958. FAO, Rome, Italy. [online] URL: http://www.fao.org/3/ i2021e/i2021e00.htm

Food and Agriculture Organization of the United Nations (FAO). 2016. The state of world fisheries and aquaculture: contributing to food security and nutrition for all. FAO, Rome, Italy. https://doi. org/10.18356/e68e16bb-en

Faught, M. 2016. Catching sustainability: an evaluation of marketoriented sustainability instruments in the global fisheries sector. Thesis. Environmental Policy Institute, Memorial University, Grenfell Campus, Corner Brook, Newfoundland.

Froese, R., and A. Proelss. 2012. Evaluation and legal assessment of certified seafood. Marine Policy 36(6):1284-1289. https://doi. org/10.1016/j.marpol.2012.03.017

Garcia, S. M., D. J. Staples, and J. Chesson. 2000. The FAO guidelines for the development and use of indicators for sustainable development of marine capture fisheries and an 
Australian example of their application. Ocean \& Coastal Management 43(7):537-556. https://doi.org/10.1016/S0964-5691 (00)00045-4

Garcia, S. M., A. Zerbi, C. Aliaume, T. Do Chi, and G. Lasserre. 2003. The ecosystem approach to fisheries. Issues, terminology, principles, institutional foundations, implementation and outlook. Food and Agriculture Organization of the United Nations, Rome, Italy.

Gavaris, S. 2009. Fisheries management planning and support for strategic and tactical decisions in an ecosystem approach context. Fisheries Research 100(1):6-14. https://doi.org/10.1016/j. fishres.2008.12.001

Government of Canada. 2008. Federal Sustainable Development Act (S.C. 2008, c.33). Government of Canada, Ottawa, Ontario, Canada. [online] URL: https://laws-lois.justice.gc.ca/eng/acts/ $\underline{\mathrm{f}-8.61}$

Granovetter, M. 1985. Economic action and social structure: the problem of embeddedness. American Journal of Sociology 91 (3):481-510.

Gréboval, D. (comp.). 2002. Report and documentation of the International Workshop on Factors Contributing to Unsustainability and Overexploitation in Fisheries: Bangkok, Thailand, 4-8 February 2002. FAO Fisheries Report. No. 672. Food and Agriculture Organization of the United Nations, Rome, Italy. [online] URL: http://www.fao.org/tempref/docrep/fao/005/y3684e/ $\mathrm{y} 3684 \mathrm{e} 00 . \mathrm{pdf}$

Helliwell, J. F., and C. Barrington-Leigh. 2010. Viewpoint: measuring and understanding subjective well-being. Canadian Journal of Economics 43(3):729-753. https://doi.org/10.1111/ j.1540-5982.2010.01592.x

Hilborn, R., and C. J. Walters. 1992. Quantitative fisheries stock assessment: choice, dynamics and uncertainty. Chapman and Hall, New York, New York, USA.

Hubbard, J. M., D. Wildish, and R. L. Stephenson. 2016. A century of maritime science: the St. Andrews Biological Station. University of Toronto Press, Toronto, Ontario, USA. https://doi. org/10.3138/9781442617278

Jacquet, J. L., and D. Pauly. 2007. The rise of seafood awareness campaigns in an era of collapsing fisheries. Marine Policy 31:308-313. https://doi.org/10.1016/j.marpol.2006.09.003

Jamieson, G., R. O'Boyle, J. Arbour, D. Cobb, S. Courtenay, R. Gregory, C. Levings, J. Munro, I. Perry, and H. Vandermeulen. 2001. Proceedings of the National Workshop on Objectives and Indicators for Ecosystem-Based Management. Canadian Science Advisory Secretariat. Proceedings Series 2001/09, 27 February-2 March 2001, Sidney, British Columbia, Canada. [online] URL: https://waves-vagues.dfo-mpo.gc.ca/Library/256094.pdf

Kooiman, J., and M. Bavinck. 2013. Theorizing governability the interactive governance perspective. Pages 9-30 in M. Bavinck, R. Chuenpagdee, S. Jentoft, and J. Kooiman, editors. Governability of fisheries and aquaculture: theory and applications. Springer, Dordrecht, The Netherlands. https://doi. org/10.1007/978-94-007-6107-0 2
Kooiman, J., and S. Jentoft. 2009. Meta-governance: values, norms and principles, and the making of hard choices. Public Administration 87(4):818-836. https://doi.org/10.1111/ j.1467-9299.2009.01780.x

Kooiman, J., S. Jentoft, R. Pullin, and M. Bavinck. 2005. Fish for life: interactive governance for fisheries. Amsterdam University Press, Amsterdam, The Netherlands. https://doi. org/10.1515/9789048505326

Leadbitter, D., and T. J. Ward. 2007. An evaluation of systems for the integrated assessment of capture fisheries. Marine Policy 31(4):458-469. https://doi.org/10.1016/j.marpol.2006.12.008

Long, R. D., A. Charles, and R. L. Stephenson. 2015. Key principles of marine ecosystem-based management. Marine Policy 57:53-60. https://doi.org/10.1016/j.marpol.2015.01.013

Lubchenco, J., and K. Grorud-Colvert. 2015. Making waves: the science and politics of ocean protection. Science 350 (6259):382-383. https://doi.org/10.1126/science.aad5443

Marine Stewardship Council (MSC). 2011. Harnessing market forces for positive change: the MSC theory of change. MSC, London, UK. [online] URL: https://www.msc.org/docs/defaultsource/default-document-library/what-we-are-doing/msc-theoryof-change-2011.pdf

Maser, C., W. Smith. 2001. Forest certification in sustainable development: healing the landscape. CRC, Boca Raton, Florida, USA.

Murray, G., T. Johnson, B. J. McCay, M. Danko, K. St. Martin, and S. Takahashi. 2010. Creeping enclosure, cumulative effects and the marine commons of New Jersey. International Journal of the Commons 4(1):367-389. https://doi.org/10.18352/bmgn$\underline{\text { lchr. } 148}$

Offe, C. 2009. Governance: “an empty signifier”? Constellations 16(4):550-562.

Ommer, R. E., R. I. Perry, G. Murray, and B. Neis. 2012. Socialecological dynamism, knowledge, and sustainable coastal marine fisheries. Current Opinion in Environmental Sustainability 4 (3):316-322. https://doi.org/10.1016/j.cosust.2012.05.010

Parlee, C. E. 2016. Resolving conflict over risk management in the marine environment: strengthening governance institutions. Dissertation. School of Graduate Studies, University of New Brunswick, Fredericton, New Brunswick, Canada. [online] URL: https://unbscholar.lib.unb.ca/islandora/object/unbscholar\%3A7858/

Parlee, C. E., and M. G. Wiber. 2018. Using conflict over risk management in the marine environment to strengthen measures of governance. Ecology and Society 23(4):5. https://doi. org/10.5751/es-10334-230405

Pitcher, T. J., and D. Preikshot. 2001. RAPFISH: a rapid appraisal technique to evaluate the sustainability status of fisheries. Fisheries Research 49(3):255-270. https://doi.org/10.1016/ $\underline{\mathrm{S} 0165-7836(00) 00205-8}$

Polanyi, K. 1957. The great transformation. Beacon Press, Boston, Massachusetts, USA. 
Pollnac, R. B., S. Abbott-Jamieson, C. Smith, M. L. Miller, P. M. Clay, and B. Oles. 2006. Toward a Model for fisheries social impact assessment. Marine Fisheries Review 68(1-4):1-18.

Ricker, W. E. 1975. The Fisheries Research Board of Canada: seventy-five years of achievements. Journal of Fisheries Research Board of Canada 32(8):1459-1464.

Shore, C. 2008. Audit culture and illiberal governance: universities and the politics of accountability. Anthropological Theory 8 (3):278-298. https://doi.org/10.1177/1463499608093815

Stephenson, R. L., S. Paul, M. Wiber, E. Angel, A. J. Benson, A. Charles, O. Chouinard, M. Clemens, D. Edwards, P. Foley, L. Jennings, O. Jones, D. Lane, J. McIsaac, C. Mussells, B. Neis, B. Nordstrom, C. Parlee, E. Pinkerton, M. Saunders, K. Squires, and U. R. Sumaila. 2018. Evaluating and implementing socialecological systems: a comprehensive approach to sustainable fisheries. Fish and Fisheries 19(5):853-873. https://doi. org/10.1111/faf.12296

Stephenson, R. L., M. Wiber, S. Paul, E. Angel, A. Benson, A. Charles, O. Chouinard, D. Edwards, P. Foley, D. Lane, J. McIsaac, B. Neis, C. Parlee, E. Pinkerton, M. Saunders, K. Squires, U. R. Sumaila. 2019. Integrating diverse objectives for sustainable fisheries in Canada. Canadian Journal of Fisheries and Aquatic Sciences 76(3):480-496. https://doi.org/10.1139/cjfas-2017-0345

Tietze, U., J. M. Le Ry, and R. Lasch. 2001. Techno-economic performance of marine capture fisheries. Food and Agriculture Organization of the United Nations, Rome, Italy.

Triantafillos, L., K. A. Brooks, J. Schirmer, S. Pascoe, T. Cannard, C. Dichmont, O. Thebaud, and E. Jebreen. 2014. Developing and testing social objectives for fisheries management. FRDC ReportProject 2010/040. Primary Industries and Regions, Adelaide, South Australia, Australia. [online] URL: https://www.frdc.com. au/Archived-Reports/FRDC\%20Projects/2010-040-DLD.pdf

United Nations. 2015. Transforming our world: the 2030 agenda for sustainable development Resolution. Adopted by the General Assembly on 25 September 2015. Seventieth Session, Agenda Items 15 and 116. A/RES/70/1. UN, New York, New York, USA.

United Nations. 2019. Millennium development goals and beyond 2015. UN, New York, New York, USA. [online] URL: http://www. un.org/millenniumgoals/bkgd.shtml

Ward, T. J. 2000. Indicators for assessing the sustainability of Australia's marine ecosystems. Marine and Freshwater Research 51(5):435-446. https://doi.org/10.1071/MF99052

Ward, T. J. 2014. The condition of Australia's marine environment is good but in decline: an integrated evidence-based national assessment by expert elicitation. Ocean \& Coastal Management 100:86-100. https://doi.org/10.1016/j.ocecoaman.2014.07.012

Weeratunge, N., C. Béné, R. Siriwardane, A. Charles, D. Johnson, E. H. Allison, P. K. Nayak, and M.-C. Badjeck. 2014. Small-scale fisheries through the wellbeing lens. Fish and Fisheries 15 (2):255-279. https://doi.org/10.1111/faf.12016 
Appendix 1. Extensive list of Example Indicators

Table A1.1: Institutional Arrangements Dimension - Example Indicators

\begin{tabular}{|c|c|}
\hline Element & Example Indicators \\
\hline $\begin{array}{l}\text { Purpose: goals and } \\
\text { objectives of the } \\
\text { governance structure } \\
\text { and processes }\end{array}$ & $\begin{array}{l}\text { - [Quantification] evidence of goals and objectives of governance } \\
\text { by [Fishing Category] } \\
\text { - [Qualitative Methods] evidence of goals and objectives of } \\
\text { governance by [Fishing Category] }\end{array}$ \\
\hline $\begin{array}{l}\text { Scope: participants, } \\
\text { geographic and temporal } \\
\text { scale and boundaries, } \\
\text { issues involved }\end{array}$ & $\begin{array}{l}\text { [Qualitative Methods] evidence of consideration of [Human } \\
\text { Population] and [Human Geographic Region] in [Management } \\
\text { Plan] } \\
\text { - } \\
\text { [Qualitative Methods] evidence of consideration of [Human } \\
\text { Population] in [General Management Activity] } \\
\end{array}$ \\
\hline $\begin{array}{l}\text { Rules: De Jure laws, } \\
\text { regulations and policies } \\
\text { as well as de facto rules } \\
\text { that structure the } \\
\text { governance process }\end{array}$ & $\begin{array}{ll}\text { - } & \text { Quantification] of [Anthropogenic Activity] covered by } \\
\text { [Institutional Arrangement] and subject to [Law] and/or } \\
\text { [Management Plan] } \\
\text { - } \\
\text { [Qualitative Methods] evidence of support for the [Institutional } \\
\text { Arrangement] and/or [Law] and/or [Management Plan] amongst } \\
\text { [Stakeholder Group] } \\
\text { - [Qualitative Methods] evidence of consistency between the } \\
\text { [Institutional Arrangement] and [Law] and [Human Population] } \\
\text { norms and values } \\
\text { - } \\
\text { Aunalitative Methods] evidence of consistency in [Institutional } \\
\text { Arrangement] between [Stakeholder Group] }\end{array}$ \\
\hline $\begin{array}{l}\text { Resources: human, } \\
\text { technical and financial } \\
\text { resources available to } \\
\text { support governance }\end{array}$ & $\begin{array}{l}\text { Level and duration of [Support] for [General Management } \\
\text { Activity] and/or [Fisheries Management Activity] amongst } \\
\text { [Stakeholder Group] and/or [Human population] at [Human } \\
\text { Geographic Region] } \\
\text { - Types of [Conflict Resolution Approaches] available to deal with } \\
\text { disputes }\end{array}$ \\
\hline
\end{tabular}


Table A1.2: Decision-making Process Dimension - Example Indicators

\begin{tabular}{|c|c|}
\hline Element & Example Indicators \\
\hline $\begin{array}{l}\text { Collaborative: } \\
\text { collaborative } \\
\text { relationships within and } \\
\text { between participants in } \\
\text { decision-making }\end{array}$ & $\begin{array}{ll}\text { - } & \text { Evidence from [Qualitative Methods] of [Stakeholder Group] } \\
\text { and [Human Population] perception of collaboration by } \\
\text { [Collaboration Type] } \\
\text { - } \\
\text { - } \\
\text { - } \text { [Quaree to which [Collaborication] of [Collaboration Criteria] exist } \\
\text { [Genentification] of [Stakeholder Group] participation in } \\
\text { Activity] } \\
\text { - Evidence from [Qualitative Methods] of [Co-operation Criteria] } \\
\text { - } \text { [Qualitative Methods] evidence of [Distribution of Authority] } \\
\text { in agreements involving [Stakeholder Group] and/or [Human } \\
\text { Population] in [Human Geographic Region] }\end{array}$ \\
\hline $\begin{array}{l}\text { Transparent: open and } \\
\text { informed policies, } \\
\text { procedures, decisions, } \\
\text { and supporting } \\
\text { documentation }\end{array}$ & $\begin{array}{ll}\text { - } & \text { [Qualitative Methods] evidence of [Stakeholder Group] and } \\
& \text { [Human Population] perception of transparency } \\
\text { - } & \text { Degree to which there is [Transparency Criteria] } \\
\text { - } & \text { [Quantification] of [Transparency Criteria] } \\
\text { - } & \text { [Qualitative Methods] evidence that selection of [Participant } \\
\text { Type] on behalf of an [Organization], [Stakeholder Group], or } \\
\text { [Human Population] is transparent. } \\
\text { - } \\
\text { [Quantification] of [Fishery Category] subject to assessment by } \\
\text { - } \text { [Qussessment Method] } \\
\text { - } \text { [Quantification] of [Data] readily accessible to the public } \\
\text { and [Stakeholder [Fishery Related Website] by [Jurisdiction] } \\
\text { - Degree to which [Information Standards] exist } \\
\text { - Degree to which [Trade-off Criteria] are identified and } \\
\text { implemented }\end{array}$ \\
\hline $\begin{array}{l}\text { Inclusive: processes that } \\
\text { support participation by } \\
\text { all parties with a } \\
\text { legitimate interest }\end{array}$ & $\begin{array}{ll}\text { - } & \text { [Qualitative Methods] evidence of [Stakeholder Group] and } \\
& \text { [Human Population] perception of inclusivity } \\
\cdot & \text { Degree to which [Inclusivity Criteria] exist } \\
\cdot & \text { [Quantification] of [Inclusivity Criteria] } \\
\cdot & \text { [Qualitative Methods] evidence of [Stakeholder Group] } \\
\text { participation in [General Management Activity] and/or } \\
\text { [Fisheries Management Activity] }\end{array}$ \\
\hline $\begin{array}{l}\text { Predictable: predictable } \\
\text { and consistent decision- } \\
\text { making procedures that } \\
\text { are not changed without } \\
\text { adequate consultation or } \\
\text { justification }\end{array}$ & $\begin{array}{ll}\text { - } & \text { QQualitative Methods] evidence of [Stakeholder Group] and } \\
& \text { [Human Population] perception of [Predictability Criteria] } \\
\text { - } & \text { Documentation of [Access] } \\
\text { - } & \text { [Qualitative Methods] evidence of changes to [Access] } \\
\text { - } & \text { Existence of [Management Plan] } \\
\text { - } & \text { [Qualitative Methods] evidence of changes to [Management } \\
& \text { Plan] } \\
\end{array}$ \\
\hline
\end{tabular}




\begin{tabular}{|c|c|}
\hline Element & Example Indicators \\
\hline $\begin{array}{l}\text { Flexible: flexible and } \\
\text { responsive processes } \\
\text { that can be adapted to } \\
\text { changing circumstances }\end{array}$ & $\begin{array}{l}\text { - [Qualitative Methods] evidence of [Stakeholder Group] and } \\
\text { [Human Population] perception of flexibility } \\
\text { - Degree to which there is [Flexibility Criteria] }\end{array}$ \\
\hline $\begin{array}{l}\text { Accountable: explicit } \\
\text { mechanisms of } \\
\text { responsibility for } \\
\text { actions, decisions and } \\
\text { outcomes }\end{array}$ & $\begin{array}{l}\text { - } \text { [Qualitative Methods] evidence of [Stakeholder Group] and } \\
\text { [Human Population] perception of accountability } \\
\text { - } \text { Qualitative Methods] evidence of [Accountability Criteria] as } \\
\text { part of [General Management Activity] and [Fisheries } \\
\text { Management Activity] } \\
\text { - } \text { [Qualitative Methods] evidence of [Accountability Criteria] in } \\
\text { [Law] and [Institutional Arrangement] } \\
\text { - } \text { QQualitative Methods] evidence of use of [Accountability } \\
\text { - } \text { [Quechanisms] } \\
\text { - } \text { [Qualitative Methods] evidence of time to respond to questions, } \\
\text { requests or issues raised by [Stakeholder Group] and/or } \\
\text { [Human Population] } \\
\text { [Quantification] of time to respond to questions, requests or } \\
\text { issues raised by [Stakeholder Group] and/or [Human } \\
\text { Population] } \\
\text { Degree to which [Accredited Organization Criteria] were } \\
\text { consulted in the development, establishment and enforcement } \\
\text { of rules at the [Rule Level] }\end{array}$ \\
\hline
\end{tabular}


Table A1.3: Outcomes Dimension - Example Indicators

\begin{tabular}{|l|l|}
\hline Element & Example Indicators \\
\hline $\begin{array}{l}\text { Effective: processes that } \\
\text { produce the intended } \\
\text { outcomes and can be } \\
\text { seen to do so }\end{array}$ & $\begin{array}{l}\text { [Qualitative Methods] evidence that [Agreement Element] of } \\
\text { [Management Plan] is/are achieved or adhered to } \\
\text { [Qualitative Methods] evidence by [Accountability Mechanism] } \\
\text { of governance process outcomes }\end{array}$ \\
\hline $\begin{array}{l}\text { Legitimate: processes } \\
\text { and outcomes that are } \\
\text { generally seen as fair } \\
\begin{array}{l}\text { and reasonable } \\
\text { regardless of self- } \\
\text { interest }\end{array}\end{array}$ & $\begin{array}{l}\text { [Qualitative Methods] evidence of [Stakeholder Group] } \\
\text { compliance with [Management Plan] by [Compliance Criteria] }\end{array}$ \\
\hline
\end{tabular}


Table A1.4: Population \& Species Dimension - Example Indicators

\begin{tabular}{|c|c|}
\hline Element & Example Indicators \\
\hline $\begin{array}{l}\text { Production \& Productivity: } \\
\text { population size and the } \\
\text { rate of change }\end{array}$ & $\begin{array}{l}\text { - } \text { [Quantification] of [Resource Demographic Category] within } \\
\text { a [Resource Geographic Region] } \\
\text { - } \text { [Quantification] of productivity of [Resource Demographic } \\
\text { Category] within a [Resource Geographic Region] } \\
\text { - } \text { [Recruitment Dynamics] description for [Resource } \\
\text { Demographic Category] } \\
\text { - } \text { [Quantification] of [Mortality] } \\
\text { - } \text { [Quantification] of escapement and relationship to } \\
\text { [Recruitment Dynamics] and [Reference Points] } \\
\text { - } \text { [Quantification] of [Mortality] by [Fishery Category] } \\
\text { - } \text { Quantification] of [Gear] modifications applied in a [Fishery } \\
\text { Category] designed to reduce [Mortality]. } \\
\text { - } \text { [Fisheries Status] of [Resource Demographic Category] } \\
\text { within a [Resource Geographic Region] } \\
\text { - Probability of changes to species' abundances associated with } \\
\text { [Regime Shift Indicators] }\end{array}$ \\
\hline $\begin{array}{l}\text { Spatial \& Temporal } \\
\text { Dynamics: geographic } \\
\text { patterns, migration routes } \\
\text { and distribution of } \\
\text { population and species }\end{array}$ & $\begin{array}{ll}\text { - } & \text { Quantification] of [Resource Demographic Category] } \\
\text { distribution during a [Time Period] } \\
\text { - } \\
\text { [Index of Abundance] in a [Resource Geographic Region] } \\
\text { during a [Time Period] in a [Resource Geographic Region] } \\
\text { - Metapopulation structure among [Resource Demographic } \\
\text { Category] in a [Resource Geographic Region] }\end{array}$ \\
\hline $\begin{array}{l}\text { Phenotypic \& Genetic } \\
\text { Diversity: differences in } \\
\text { morphology of individuals } \\
\text { due to environmental and } \\
\text { genetic variation }\end{array}$ & $\begin{array}{l}\text { [Genetic Diversity] and/or [Phenotypic Diversity] among a } \\
\text { [Resource Demographic Category] within a [Resource } \\
\text { Geographic Region] } \\
\text { - Change in [Genetic Diversity] and [Phenotypic Diversity] } \\
\text { among a [Resource Demographic Category] over [Time } \\
\text { Period] } \\
\text { - Reproduction potential based on [Genetic Diversity] and/or } \\
\text { [Phenotypic Diversity] among a [Resource Demographic } \\
\text { Category] }\end{array}$ \\
\hline
\end{tabular}


Table A1.5: Habitat \& Environment Dimension - Example Indicators

\begin{tabular}{|c|c|}
\hline Element & Example Indicators \\
\hline $\begin{array}{l}\text { Substrate Quality: } \\
\text { condition of biotic and } \\
\text { abiotic structures used by } \\
\text { aquatic organisms during } \\
\text { their life cycle, including } \\
\text { extent, availability and } \\
\text { quality }\end{array}$ & $\begin{array}{l}\text { - Substrate characteristics mapped and the degree of impact, by } \\
\text { [Anthropogenic Activity] } \\
\text { - } \text { [Quantification] of [Gear] modifications applied in a [Fishery } \\
\text { Category] designed to reduce impact to substrate quality } \\
\text { - } \quad \text { [Quantification] of nursery, spawning or sensitive areas } \\
\text { - Proportion of sensitive or rare [Biogenic Species] subject to } \\
\text { [Anthropogenic Activity] } \\
\text { - Proportion of biogenic structures surveyed and mapped, and } \\
\text { the degree of impact, by [Anthropogenic Activity] } \\
\text { - Habitat Maps considering presence/absence and abundance of } \\
\text { [Biogenic Species] } \\
\text { [Quantification] of [Gear] modifications applied in a [Fishery } \\
\text { Category] designed to reduce impact to biogenic structures }\end{array}$ \\
\hline $\begin{array}{l}\text { Water Quality: water } \\
\text { quality and column } \\
\text { properties including extent } \\
\text { and availability }\end{array}$ & $\begin{array}{ll}\text { - } & \text { [Quantification] of [Pollution] in a [Resource Geographic } \\
& \text { Region] } \\
\text { - } & \text { [Quantification] of anoxic zones in a [Resource Geographic } \\
& \text { Region] } \\
\text { - } & \text { [Eutrophication Indicator] in a [Resource Geographic Region] } \\
\cdot & \text { Risk assessments for major catastrophic [Pollution] events } \\
- & \text { [Quantification] of [Pollution] over [Time Period] } \\
- & \text { [Quantification] of introduction and proliferation of } \\
\text { disease/pathogens. } & \text { [Quantification] of water in migration pathways. } \\
- & \text { [Quantification] and mapping of pelagic pathways. } \\
- & \text { Probability of climate-change induced regime shift using } \\
& \text { [Regime Shift Indicators] } \\
\end{array}$ \\
\hline $\begin{array}{l}\text { Productivity Capacity: the } \\
\text { natural equilibrium } \\
\text { capability of habitats to } \\
\text { produce healthy fish } \\
\text { stocks and aquatic } \\
\text { organisms on which fish } \\
\text { depend }\end{array}$ & $\begin{array}{ll}\cdot & \text { [Quantification] of [Eutrophication Indicator] } \\
\text { - } & \text { [Quantification] of historic bounds of primary productivity }\end{array}$ \\
\hline
\end{tabular}


Table A1.6: Ecosystem Structure \& Functionality Dimension - Example Indicators

\begin{tabular}{|c|c|}
\hline Element & Example Indicators \\
\hline $\begin{array}{l}\text { Biodiversity: number and } \\
\text { variety of organisms } \\
\text { within a particular } \\
\text { ecosystem }\end{array}$ & $\begin{array}{ll}\text { - } & \text { [Quantification] of [Biodiversity Indices] in a [Resource } \\
& \text { Geographic Region] } \\
\text { - } & \text { [Quantification] of change in [Biodiversity Indices] over } \\
& \text { [Time Period] } \\
\text {. } & \text { [Quantification] of non-native species in ecosystem }\end{array}$ \\
\hline $\begin{array}{l}\text { Food \& Interaction Webs: } \\
\text { energy flows and } \\
\text { interactions between } \\
\text { trophic levels and } \\
\text { populations in an } \\
\text { ecosystem }\end{array}$ & $\begin{array}{l}\text { [Quantification] and [Qualitative Methods] evidence of } \\
\text { [Food-web Interactions] that enhance/maintain [Food-web } \\
\text { Stability] } \\
\text { - Influence of [Anthropogenic Activity] on [Food-web } \\
\text { Interactions] and [Food-web Stability]. } \\
\text { [Quantification] of changes to [Food-web Interactions] over } \\
\text { [Time Period] } \\
\text { Degree of impact of non-native species on [Food-web } \\
\text { Interactions] and [Food-web Stability] }\end{array}$ \\
\hline $\begin{array}{l}\text { Regime Shifts: persistent } \\
\text { changes in the structure } \\
\text { and function of an } \\
\text { ecosystem }\end{array}$ & $\begin{array}{l}\text { - } \text { [Quantification] of changes in primary or trophic level } \\
\text { productivity reflected by [Regime Shift Indicators] } \\
\text { - } \text { [Quantification] of changes to community or trophic structure } \\
\text { reflected by [Regime Shift Indicators] } \\
\text { - } \\
\text { [Quantification] of changes to [Food-web Stability] reflected } \\
\text { by [Regime Shift Indicators] } \\
\text { - Non-native and/or competing species impacts on [Regime } \\
\text { Shift Indicators] }\end{array}$ \\
\hline
\end{tabular}


Table A1.7: Health \& Wellbeing Dimension - Example Indicators

\begin{tabular}{|c|c|}
\hline Element & Example Indicators \\
\hline $\begin{array}{l}\text { Material Wellbeing: } \\
\text { basic needs, physical } \\
\text { welfare and standards of } \\
\text { living }\end{array}$ & 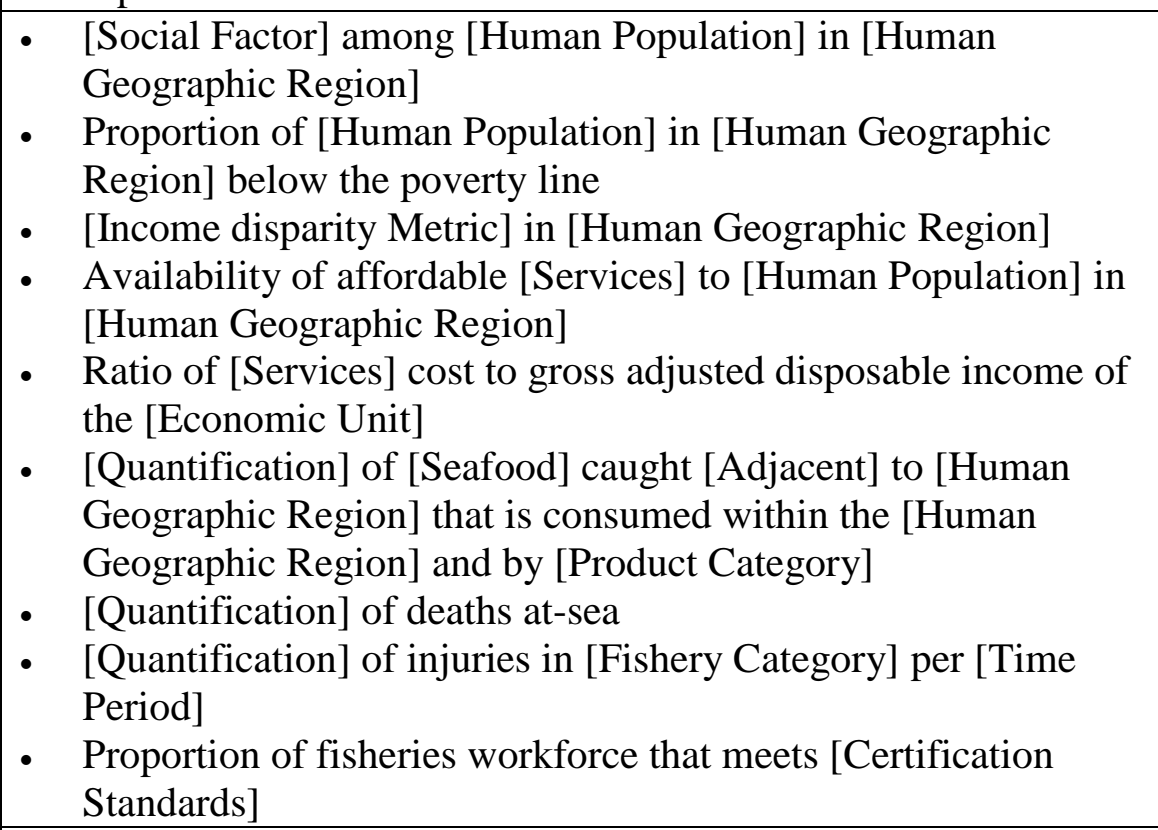 \\
\hline $\begin{array}{l}\text { Relational Wellbeing: } \\
\text { relations of love and } \\
\text { care, networks of } \\
\text { support and obligation, } \\
\text { social, political and } \\
\text { cultural identities }\end{array}$ & $\begin{array}{l}\text { - } \text { Qualitative Methods] evidence of subjective perception of } \\
\text { shared values and norms within a [Human Population] in a } \\
\text { [Human Geographic Region] } \\
\text { - } \text { [Quantification] of social networks within a [Human } \\
\text { Population] in a [Human Geographic Region] } \\
\text { - } \text { [Qualitative Methods] evidence of participation in } \\
\text { [Organizations] within a [Human Population] in a [Human } \\
\text { Geographic Region] } \\
\text { - The [Organization Condition] of [Organizations] in a [Human } \\
\text { Geographic Region] } \\
\text { - Voter turnout in a [Human Geographic Region] for } \\
\text { [Jurisdiction] election among [Human Population] }\end{array}$ \\
\hline $\begin{array}{l}\text { Subjective Wellbeing: } \\
\text { personal perception of } \\
\text { individual and collective } \\
\text { health and wellbeing, } \\
\text { sense of agency and } \\
\text { self-efficacy }\end{array}$ & $\begin{array}{l}\text { Rating of importance of fisheries in opinion polls in [Human } \\
\text { Geographic Region] among [Human Population] } \\
\text { - Stated preference valuation for the existence of fisheries } \\
\text { dependent communities in [Human Geographic Region] } \\
\text { - [Qualitative Methods] evidence of subjective perception of self- } \\
\text { efficacy within the [Human Geographic Region] } \\
\text { - } \text { [Qualitative Methods] evidence of attachment to place within } \\
\text { the [Human Geographic Region] } \\
\text { - } \text { [Quantification] of social mobility within the [Human } \\
\text { Geographic Region] } \\
\text { - [Qualitative Methods] evidence of subjective perception of } \\
\text { well-being within the [Human Geographic Region] }\end{array}$ \\
\hline
\end{tabular}


Table A1.8: Economics \& Finance Dimension - Example Indicators

\begin{tabular}{|c|c|}
\hline Element & Example Indicators \\
\hline $\begin{array}{l}\text { Economic Efficiency: } \\
\text { value obtained from the } \\
\text { resource relative to } \\
\text { costs, waste and } \\
\text { negative externalities }\end{array}$ & 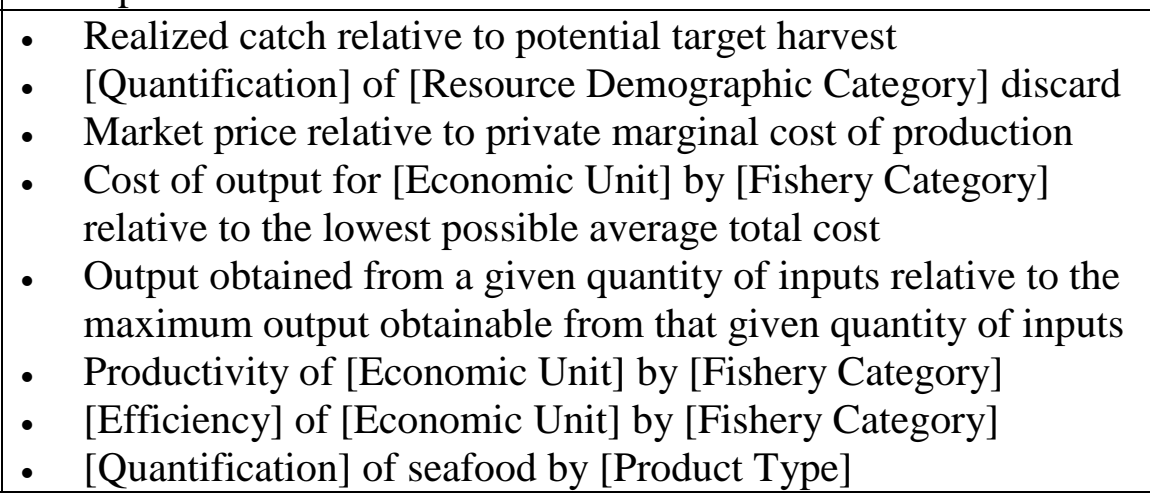 \\
\hline $\begin{array}{l}\text { Financial Viability: } \\
\text { financial health of } \\
\text { enterprises and other } \\
\text { institutions involved in } \\
\text { the fishery }\end{array}$ & $\begin{array}{l}\text { - Net profit of enterprises by [Value Chain Element], [Fishery } \\
\text { Category] and [Gear] } \\
\text { Bankruptcy rate for participants by [Value Chain Element], } \\
\text { [Fishery Category] and [Gear] } \\
\text { - Investment stock/flow in fishery, by [Value Chain Element], } \\
\text { [Fishery Category], [Operator Type] and [Gear] } \\
\text { - Availability of capital/debt financing by [Value Chain } \\
\text { Element], [Fishery Category], [Operator Type] and [Gear] } \\
\text { - [Financial ratio] by [Value Chain Element], [Fishery Category], } \\
\text { [Operator Type] and [Gear] } \\
\text { - } \text { [Quantification] of enterprises dependent on one fishery } \\
\text { - Number of [Fishery Category] that fishing enterprises } \\
\text { participate in } \\
\text { - Proportion of investment stock/flow in depreciating assets } \\
\text { versus [Access] by [Operator Type] }\end{array}$ \\
\hline $\begin{array}{l}\text { Economic \& Financial } \\
\text { Sustainability: } \\
\text { sustainability of profits } \\
\text { at all stages of the value } \\
\text { chain }\end{array}$ & $\begin{array}{ll} & \text { Economic sustainability index } \\
\text { - } & \text { [Financial Information] trends } \\
\text { - } & \text { Value of [Economic Variables] by [Fishery Category] } \\
\text { - } & \text { [Quantification] of [Economic Variables] by [Value Chain } \\
& \text { Element] in [Human Geographic Region] } \\
\text { - } & \text { Availability of [Occupational Axis] with the required } \\
& \text { [Experience], [Education] and [Certification Standards] } \\
\text { - } & \text { Presence/absence of [Law] to restrict [Market Failure] } \\
\text { - } & \text { [Enforcement] of restrictions on [Market Failure] } \\
\text { - } & \text { [Quantification] of [Labour Tactic] }\end{array}$ \\
\hline $\begin{array}{l}\text { Equity: fairness in how } \\
\text { costs and benefits of the } \\
\text { fishery are distributed } \\
\text { amongst participants }\end{array}$ & $\begin{array}{ll}\cdot & \text { [Income Disparity Metric] in [Human Geographic Region] } \\
\cdot & \text { Distribution of [Value Type] by [Value Chain Element] } \\
\cdot & \text { Distribution of [Value Type] by [Operator Type] } \\
\cdot & \text { Loss of [Benefit Axis] from reallocation of access from } \\
& \text { [Economic Unit] in [Human Geographic Region] } \\
\cdot & \text { [Quantification] of [Seafood] harvest across [Fishery Category] }\end{array}$ \\
\hline
\end{tabular}




\begin{tabular}{|c|c|}
\hline Element & Example Indicators \\
\hline & $\begin{array}{ll}\text { being contested by one or more [Stakeholder Group] } \\
\text { Distribution of catch by [Fishery Category], [Human } \\
\text { Geographic Region], and [Economic Unit] } \\
\text { - } \\
\text { Distribution of [Access] by [Human Geographic Region], } \\
\text { [Human Population], [Fishery Category], [Operator Type] } \\
\text { [Quantification] of major changes to [Access] conditions over } \\
\text { [Time Period] } \\
\text { - } \\
\text { - } \\
\text { - } \\
\text { - Distribution of [Value Type] by [Value Chain Element] } \\
\text { - } & \text { Distribution of [Value Type] by [Operator Type] } \\
\text { [Risk Axis] by [Socio-economic Distribution Axis] }\end{array}$ \\
\hline
\end{tabular}


Table A1.9: Social Justice Dimension - Example Indicators

\begin{tabular}{|c|c|}
\hline Element & Example Indicators \\
\hline $\begin{array}{l}\text { Poverty \& Livelihoods: } \\
\text { consideration of the } \\
\text { interests of the poor and } \\
\text { fishing livelihoods in the } \\
\text { management of the } \\
\text { resource }\end{array}$ & $\begin{array}{ll}\text { - } & \text { Qualitative Methods] evidence of subjective perception of the } \\
\text { viability of livelihoods among [Human Population] in [Human } \\
\text { Geographic Region] } \\
\text { - } \\
\text { - } \text { [Quantification] of [Livelihood Index] by [Occupational Axis] } \\
\text { - } \\
\text { [Quantification] of [Social Factor] in fishery-dependent [Human } \\
\text { Geographic Region] } \\
\cdot \text { [Quantification] of [Social Factor] gains and losses among } \\
\text { [Human Population] in [Human Geographic Region] } \\
\text { [Qualitative Methods] evidence of poverty and livelihoods in } \\
\text { [Human Geographic Region] being taken into account in } \\
\text { [Management Plan] } \\
\text { - } \text { [Experience] and [Education] by [Occupational Axis], [Fishery } \\
\text { - Category] and [Gear] } \\
\text { [Quantification] of [Labour Tactic] }\end{array}$ \\
\hline $\begin{array}{l}\text { Women \& Gender: } \\
\text { consideration of the } \\
\text { interests of women and } \\
\text { gender issues in the } \\
\text { management of the } \\
\text { resource }\end{array}$ & $\begin{array}{l}\text { [Qualitative Methods] evidence of women and gender issues in } \\
\text { [Human Geographic Region] being taken into account in } \\
\text { [Management Plan] } \\
\text { - } \\
\text { [Quantification] of [Experience] of women in [Fishing } \\
\text { Category] } \\
\text { - } \\
\text { byantification of participation in [Fishing Category] by women } \\
\text { buantificational Axis] } \\
\text { Activity] by women by [Occupational Axis] }\end{array}$ \\
\hline $\begin{array}{l}\text { Fishing Communities: } \\
\text { consideration of the } \\
\text { interests of fishing } \\
\text { communities in the } \\
\text { management of the } \\
\text { resource }\end{array}$ & $\begin{array}{ll}\text { - } & \text { Qualitative Methods] evidence of fishing communities in } \\
\text { [Human Geographic Region] being taken into account in } \\
\text { [Management Plan] } \\
\text { - Value of [Fisheries Related Public Infrastructure] in [Human } \\
\text { Geographic Region] } \\
\text { - Value of [Fisheries Related Private Infrastructure] in [Human } \\
\text { Geographic Region] } \\
\text { - } \\
\text { [Quantification] of [Risk Axis] by [Human Geographic Region] } \\
\text { [Human Population] in [Human Geographic Region] }\end{array}$ \\
\hline $\begin{array}{l}\text { Indigenous Peoples: } \\
\text { consideration of the } \\
\text { interests of Indigenous } \\
\text { peoples in the } \\
\text { management of the } \\
\text { resource }\end{array}$ & $\begin{array}{l}\text { - Quantification of participation in [Fishing Category] by } \\
\text { Indigenous Peoples by [Occupational Axis] } \\
\text { - Quantification of participation in [Fishing Management } \\
\text { Activity] by Indigenous Peoples } \\
\text { - [Qualitative Methods] evidence of Indigenous Peoples in } \\
\text { [Human Geographic Region] being taken into account in } \\
\text { [Management Plan] }\end{array}$ \\
\hline
\end{tabular}




\begin{tabular}{|c|c|}
\hline Element & Example Indicators \\
\hline & $\begin{array}{ll}\text { - } & \text { [Law] protecting rights of Indigenous Peoples } \\
\text { - } & \text { [Law] requiring consideration of traditional knowledge of } \\
\text { Indigenous Peoples } \\
\text { - } \\
\text { [Qualitative Methods] evidence of participation in [General } \\
\text { Management Activity] by [Fishing Category] } \\
\text { - } \quad \text { Quantification] of [Benefit Axis] by Indigenous group }\end{array}$ \\
\hline $\begin{array}{l}\text { Future Generations: } \\
\text { consideration of the } \\
\text { interests of future } \\
\text { generations in the } \\
\text { management of the } \\
\text { resource }\end{array}$ & $\begin{array}{ll}\text { - } & \text { [Quantification] of [Natural Capital] stocks } \\
\text { - } & \text { [Quantification] of rate of depletion of [Natural Capital] stocks } \\
\text { - } & \text { [Qualitative Methods] evidence of substitutability of human and } \\
\text { physical capital for [Natural Capital] stocks } \\
\text { - } \\
\text { [Qualitative Methods] evidence of future generations in } \\
\text { [Human Geographic Region] being taken into account in } \\
\text { [Management Plan] }\end{array}$ \\
\hline
\end{tabular}


Table A1.10: ATTRIBUTES

\begin{tabular}{|c|c|}
\hline Attribute & Examples of Attribute \\
\hline Access & $\begin{array}{l}\text { open access; licence; quota; individually allocated } \\
\text { access; hereditary right; communal access }\end{array}$ \\
\hline Accountability Criteria & $\begin{array}{l}\text { documented roles and responsibilities; explicit } \\
\text { consequences for non-performance of duties; binding } \\
\text { commitments to } 3^{\text {rd }} \text { party standards; agreements to } \\
\text { adhere to appropriate professional codes of conduct }\end{array}$ \\
\hline Accountability Mechanism & $\begin{array}{l}\text { reports and disclosure statements; performance } \\
\text { assessments and evaluations; risk assessments; self- } \\
\text { regulation; social audits; protests; campaigns }\end{array}$ \\
\hline Accredited Organization Criteria & $\begin{array}{l}\text { represents members; requires members to pay an annual } \\
\text { due; maintains a duly elected executive; has established } \\
\text { and maintains a reporting mechanism; has made } \\
\text { required filings and registration with appropriate public } \\
\text { bodies; maintains minimum membership size }\end{array}$ \\
\hline Adjacent & $\begin{array}{l}\text { within } 10 \text { miles; within } 100 \text { miles; in province; in } \\
\text { country, Exclusive Economic Zone }\end{array}$ \\
\hline Agreement & $\begin{array}{l}\text { conditional sales agreement; trust agreement; minimum } \\
\text { price agreement; collective agreement; treaty }\end{array}$ \\
\hline Agreement Element & $\begin{array}{l}\text { goals \& objectives; terms of reference; statement of } \\
\text { roles and responsibilities; duration and renewal } \\
\text { conditions; liability and accountability provisions; } \\
\text { dispute resolution mechanisms; audit and evaluation } \\
\text { conditions }\end{array}$ \\
\hline Anthropogenic Activity & $\begin{array}{l}\text { harvesting; shipping; tourism and recreation; oil and gas } \\
\text { extraction/processing; mining; forestry; aquaculture; } \\
\text { construction; residential development }\end{array}$ \\
\hline Assessment Method & $\begin{array}{l}\text { performance based audit; program evaluation; fishery } \\
\text { management plan evaluation; third-party fisheries } \\
\text { certification assessment; management strategy } \\
\text { evaluation; CFRN indicator framework }\end{array}$ \\
\hline Benefit Axis & $\begin{array}{l}\text { employment; access (quota, licence); physical capital } \\
\text { (e.g., vessels); income; revenue; food; opportunity }\end{array}$ \\
\hline Biodiversity Indices & $\begin{array}{l}\text { species richness; Shannon's diversity; species } \\
\text { assemblage structure; slope of size spectra; abundance } \\
\text { of keystone species }\end{array}$ \\
\hline Biogenic Species & $\begin{array}{l}\text { corals; sponge; crystalline algae; bivalves; oysters; } \\
\text { scallops; mussels; sea grass. }\end{array}$ \\
\hline Certification Standards & $\begin{array}{l}\text { occupational first aid; marine emergency duties; } \\
\text { master's ticket; engineer's ticket, post- secondary } \\
\text { degree. }\end{array}$ \\
\hline
\end{tabular}




\begin{tabular}{|c|c|}
\hline Attribute & Examples of Attribute \\
\hline Collaboration Criteria & $\begin{array}{l}\text { power-sharing; information-sharing; shared rule- } \\
\text { making; multi-party agreements signed and/or renewed; } \\
\text { multi-party management plans }\end{array}$ \\
\hline Collaboration Criteria & $\begin{array}{l}\text { power-sharing; information-sharing; shared rule- } \\
\text { making; multi-party agreements signed and/or renewed; } \\
\text { multi-party management plans; mechanisms for conflict } \\
\text { and conflict resolution. }\end{array}$ \\
\hline Collaboration Type & $\begin{array}{l}\text { public-private partnerships; private-social partnerships; } \\
\text { co-management }\end{array}$ \\
\hline Compensation & payment; wage; share; bonus \\
\hline Compliance Criteria & $\begin{array}{l}\text { conformation to rules, regulations, plans, policies, } \\
\text { standards, agreements, laws and administrative } \\
\text { specifications; requirement of and conformity to } \\
\text { covenants of permits, certificates, licenses or leases; } \\
\text { penalties in place to address infractions such as fines, } \\
\text { seizure of harvest }\end{array}$ \\
\hline Conflict Resolution Approaches & $\begin{array}{l}\text { facilitative approach; mediation; negotiation; arbitration; } \\
\text { rights-based court system; rule based processes; } \\
\text { transformative approach; interest based approach; } \\
\text { evaluative approach; activist approach; narrative } \\
\text { approach }\end{array}$ \\
\hline Co-operation Criteria & $\begin{array}{l}\text { disputed decisions; disputes resolved; availability of } \\
\text { third-party conflict resolution services; use of third party } \\
\text { conflict resolution services; ministerial intervention }\end{array}$ \\
\hline Cost Axis & $\begin{array}{l}\text { loss of capital; loss of human life; human health } \\
\text { impacts; habitat loss; ecosystem service losses; } \\
\text { opportunity costs; foregone revenues }\end{array}$ \\
\hline Data & $\begin{array}{l}\text { federal fisheries data that does not violate privacy, } \\
\text { confidentiality or national security requirements; federal } \\
\text { fisheries catch data; federal fisheries stock assessment } \\
\text { data; federal fisheries quota transaction data; provincial } \\
\text { fisheries processing data; fisheries ownership data }\end{array}$ \\
\hline Distribution of Authority & $\begin{array}{l}\text { co-management; collaborative governance; subsidiarity; } \\
\text { delegation of powers }\end{array}$ \\
\hline Economic Unit & individual; household; enterprise; fishery; industry \\
\hline Economic Variables & $\begin{array}{l}\text { price; rent; subsidies; externalities; consumer surplus; } \\
\text { producer surplus; GDP }\end{array}$ \\
\hline Education & $\begin{array}{l}\text { primary school, some high school; high school graduate; } \\
\text { some postsecondary; postsecondary certificate or } \\
\text { diploma; bachelor's degree; master's degree; doctorate's } \\
\text { degree }\end{array}$ \\
\hline Efficiency & allocative efficiency; productive efficiency; technical \\
\hline
\end{tabular}




\begin{tabular}{|c|c|}
\hline Attribute & Examples of Attribute \\
\hline & efficiency \\
\hline Enforcement & arrest, prosecution, fine, jail term, seizure \\
\hline Eutrophication Indicator & $\begin{array}{l}\text { nutrient concentrations; Chlorophyll A concentration; } \\
\text { index of water clarity; hypoxia; algal blooms; changes } \\
\text { phytoplankton communities; fish kills }\end{array}$ \\
\hline Experience & $\begin{array}{l}\text { months or years working in industry; position } \\
\text { (deckhand, skipper); fisheries }\end{array}$ \\
\hline Financial Information & $\begin{array}{l}\text { licence value; quota value; share value; wages; price; } \\
\text { revenues; costs; profits }\end{array}$ \\
\hline Financial Ratio & $\begin{array}{l}\text { cash ratio; current ratio; effective tax rate; return on } \\
\text { equity; debt to equity; cash flow to debt; price/earnings } \\
\text { ratio; dividend yield }\end{array}$ \\
\hline Fisheries Management Activity & $\begin{array}{l}\text { monitoring; enforcement; stock assessment; research; } \\
\text { habitat monitoring; habitat protection; habitat } \\
\text { restoration; habitat enhancement; harvest planning; } \\
\text { harvest management; evaluation }\end{array}$ \\
\hline Fisheries Related Private Infrastructure & $\begin{array}{l}\text { vessels; processing plants; service providers; } \\
\text { manufacturers }\end{array}$ \\
\hline Fisheries Related Public Infrastructure & $\begin{array}{l}\text { wharves, docks, piers; coast guard facilities; research } \\
\text { stations and vessels; stock enhancement facilities }\end{array}$ \\
\hline Fishery Category & $\begin{array}{l}\text { fishery (by species, multi-species, gear, market); fleet } \\
\text { (by vessel size, ownership, gear) }\end{array}$ \\
\hline Fishery Related Website & $\begin{array}{l}\text { DFO website; industry association website; community } \\
\text { association fisheries website; ENGO fisheries website }\end{array}$ \\
\hline Fishery Status & $\begin{array}{l}\mathrm{B}_{\mathrm{t}} / \mathrm{B}_{\mathrm{target}} ; \mathrm{B}_{\mathrm{t}} / \mathrm{B}_{\lim } ; \mathrm{B}_{\mathrm{t}} / \mathrm{B}_{0} ; \text { probability of extinction; } \\
\text { COSEWIC/IUCN designated unit status }\end{array}$ \\
\hline Flexibility Criteria & $\begin{array}{l}\text { adherence to process and precedent; consideration of } \\
\text { range, time, change, conditions of uncertainty and } \\
\text { favourability; consideration of trigger events, trigger } \\
\text { states, decisions and choices; distinguish between } \\
\text { flexible, inflexible and degrees of flexibility }\end{array}$ \\
\hline Food Web Interactions & $\begin{array}{l}\text { metabolic respiration; energy flow; carbon flow; niche } \\
\text { width, diet composition and index of complexity, } \\
\text { number of trophic levels, species/life stage size spectra; } \\
\text { food web complexity; abundance of alternate prey }\end{array}$ \\
\hline Food Web Stability & $\begin{array}{l}\text { CV of biomass; Eigenvalue from community matrix } \\
\text { interactions. }\end{array}$ \\
\hline Gear & $\begin{array}{l}\text { nets; traps; hooks; longline; trawl; troll; gillnet; seine; } \\
\text { trap; hook and line; dive }\end{array}$ \\
\hline General Management Activity & $\begin{array}{l}\text { regional advisory processes; government budget } \\
\text { allocation processes; management agency administration } \\
\text { processes; science advisory processes; management }\end{array}$ \\
\hline
\end{tabular}




\begin{tabular}{|c|c|}
\hline Attribute & Examples of Attribute \\
\hline & agency hiring processes \\
\hline Genetic Diversity & $\begin{array}{l}\text { Gene diversity, Heterozygosity variation and } \\
\text { microsatellites and mitochondrial DNA; genetic mixing; } \\
\text { genetic sex ratio }\end{array}$ \\
\hline Human Geographic Region & $\begin{array}{l}\text { country; province; region; community; First Nation } \\
\text { territory }\end{array}$ \\
\hline Human Population & $\begin{array}{l}\text { general human population; fisheries participants; } \\
\text { aboriginal people; youth; women; men; coastal } \\
\text { communities }\end{array}$ \\
\hline Inclusivity Criteria & $\begin{array}{l}\text { access to funding; access to other resources; attendance } \\
\text { at meetings; participation rates at public hearings; travel } \\
\text { time between fishing communities \& meeting locations; } \\
\text { membership in stakeholder groups }\end{array}$ \\
\hline Income Disparity Metric & $\begin{array}{l}\text { Gini coefficient; ratio of highest wage to average wage; } \\
\text { proportion below poverty line }\end{array}$ \\
\hline Index of Abundance & $\begin{array}{l}\text { CPUE; WPUE; survey estimates; stock assessment } \\
\text { biomass/abundance estimates }\end{array}$ \\
\hline Information Standards & $\begin{array}{l}\text { allocation decisions include explicit trade-off analysis; } \\
\text { decisions include risk assessment; peer review of } \\
\text { science; knowledge of legal and regulatory framework; } \\
\text { indicators are SMART; use of EBM approaches; } \\
\text { application of precautionary approach; incorporation of } \\
\text { local and traditional knowledge; multi-disciplinarity; } \\
\text { MSE; Bayesian Decision Networks }\end{array}$ \\
\hline Institutional Arrangement & $\begin{array}{l}\text { legislation; regulation; policy; programs; management } \\
\text { structures }\end{array}$ \\
\hline Jurisdiction & federal; provincial; municipal; First Nation \\
\hline Labour tactic & strike; blacklist; boycott, media \\
\hline $\begin{array}{l}\text { Law } \\
\text { (inclusive of soft and hard laws) }\end{array}$ & $\begin{array}{l}\text { Fisheries Act; Oceans Act; Marine Stewardship Council } \\
\text { (MSC) certification; industry association regulations; } \\
\text { Aboriginal and treaty rights to fish }\end{array}$ \\
\hline Livelihood Index & $\begin{array}{l}\text { Sustainable Livelihood Security Index; Economic } \\
\text { Security Index }\end{array}$ \\
\hline Management Plan & $\begin{array}{l}\text { Integrated Fisheries Management Plan; marine use plan; } \\
\text { land use plan; harvest plan }\end{array}$ \\
\hline Market Failure & $\begin{array}{l}\text { corporate concentration; insider trading; undue market } \\
\text { control; transfer pricing; price gouging; price-fixing }\end{array}$ \\
\hline Mortality & $\begin{array}{l}\text { Fishing mortality; Target Fishing mortality; Natural Mort } \\
\text { Incidental Mortality }\end{array}$ \\
\hline Natural Capital & $\begin{array}{l}\text { fish; wildlife; forests; water resources; air; energy } \\
\text { sources; minerals }\end{array}$ \\
\hline
\end{tabular}




\begin{tabular}{|c|c|}
\hline Attribute & Examples of Attribute \\
\hline Occupational Axis & $\begin{array}{l}\text { skipper; deckhand; tenderman; diver; shoreworker; } \\
\text { technician; fisheries observer; fisheries scientist; } \\
\text { processor; fisheries manager; fisheries researcher }\end{array}$ \\
\hline Operator Type & $\begin{array}{l}\text { processor with fisheries access rights; non-participating } \\
\text { access owner (investor); owner-operator; active } \\
\text { fishermen without ownership access }\end{array}$ \\
\hline Organization Condition & number of; participation rates in; funding for \\
\hline Organization & $\begin{array}{l}\text { arts organizations; cultural institutions; social } \\
\text { organizations; environmental organizations; political } \\
\text { organizations; industry associations; union }\end{array}$ \\
\hline Participant Type & representative; delegate; observer; expert; facilitator \\
\hline Phenotypic Diversity & $\begin{array}{l}\text { phenotypic variation in measurable characteristics; } \\
\text { maturation-at-age; size-at-age; phenotypic sex ratio, } \\
\text { meristics. }\end{array}$ \\
\hline Pollution & $\begin{array}{l}\text { thermal \& heated water; sewage; debris; oil discharge; } \\
\text { noise; light }\end{array}$ \\
\hline Power Dynamics Criteria & $\begin{array}{l}\text { sources of power imbalances (personal, relational, data, } \\
\text { technological, professional, structural, educational, } \\
\text { capacity etc.); types of power relations (citizen, } \\
\text { delegated or power over, partnership or power with, } \\
\text { powerless, empowered, coercive, cooperative); power } \\
\text { holders }\end{array}$ \\
\hline Predictability Criteria & $\begin{array}{l}\text { clearly established and communicated processes for } \\
\text { decision making; following plain meaning of a process } \\
\text { or provision; pursue process as it was intended by } \\
\text { drafters; follow precedent }\end{array}$ \\
\hline Processing Type & $\begin{array}{l}\text { fresh; fresh-frozen; frozen-at-sea; smoked; fish product } \\
\text { (e.g., surimi); canned; fishmeal }\end{array}$ \\
\hline Product Category & $\begin{array}{l}\text { landed; processed; available for sale; consumed; } \\
\text { exported from }\end{array}$ \\
\hline Qualitative Methods & $\begin{array}{l}\text { survey; focus group; interview; public hearing; public } \\
\text { inquiry; study; legal proceedings; media article }\end{array}$ \\
\hline Quantification & $\begin{array}{l}\text { proportion; number; frequency; total area; total volume; } \\
\text { presence/absence; ratio }\end{array}$ \\
\hline Recruitment Dynamics & $\begin{array}{l}\text { shape of recruitment curve; compensation or } \\
\text { depensation; changes in average recruitment }\end{array}$ \\
\hline Reference Points & $\begin{array}{l}\text { limit reference points; upper reference points; target } \\
\text { reference points }\end{array}$ \\
\hline Regime Shift Indicators & $\begin{array}{l}\text { changes in trophic level; changes in individual size; end- } \\
\text { to-end ecosystem models; ecosystem exploitation index; } \\
\text { water acidification; changes in water/air temperature. }\end{array}$ \\
\hline Resource Demographic Category & species; population; stock; size; sex; age; class. \\
\hline
\end{tabular}




\begin{tabular}{|c|c|}
\hline Attribute & Examples of Attribute \\
\hline Resource Geographic Region & $\begin{array}{l}\text { province; country; Exclusive Economic Zone; region; } \\
\text { management area; marine area; river system; lake; } \\
\text { watershed }\end{array}$ \\
\hline Risk Axis & ecological; financial; economic; health; cultural \\
\hline Rule Level & constitutional level; collective level; operational level \\
\hline Seafood & $\begin{array}{l}\text { by species grouping (e.g., salmon, groundfish); species } \\
\text { (e.g., chum salmon, prawns); gear and species } \\
\text { (e.g., gillnet-caught chum salmon) }\end{array}$ \\
\hline Sector & commercial; recreational; food; cultural \\
\hline Services & education; housing; daycare; medical care \\
\hline Social Factor & $\begin{array}{l}\text { suicide rate; infant mortality rate; unemployment rate; } \\
\text { migration rate; employment rate; life expectancy; real } \\
\text { per capita income; job satisfaction level employment } \\
\text { rate; life expectancy; real per capita income; job } \\
\text { satisfaction level }\end{array}$ \\
\hline Socio-economic Distribution Axis & $\begin{array}{l}\text { gender; age; sector; fishery; region; community; } \\
\text { enterprise; vessel; harvester; individual }\end{array}$ \\
\hline Stakeholder Group & $\begin{array}{l}\text { Indigenous communities; processors; trade unions; } \\
\text { fishermen's associations; industry associations; } \\
\text { recreational users; regional government; community } \\
\text { groups; environmental interests; provincial government }\end{array}$ \\
\hline Support & financial; human resources; technical; logistical \\
\hline Technological Impacts & $\begin{array}{l}\text { deskilling; loss of customary or traditional knowledge; } \\
\text { generation gaps; job losses }\end{array}$ \\
\hline Time Period & day; week, month; season; year; decade; century \\
\hline Trade-off Criteria & $\begin{array}{l}\text { qualitative and quantitative frameworks to discuss trade- } \\
\text { offs; clarified decision context; clear statement of and } \\
\text { justification for trade-offs; evaluation and selection of } \\
\text { trade-offs; assignment of ranks or preferences for } \\
\text { alternatives; estimation of risk (objective and subjective) }\end{array}$ \\
\hline Transparency Criteria & $\begin{array}{l}\text { availability of information; usability of available } \\
\text { information; public release of rationale for decision }\end{array}$ \\
\hline Value Chain Element & $\begin{array}{l}\text { producer; processor; buyer; wholesaler; retailer; } \\
\text { consumer; investor }\end{array}$ \\
\hline Value Type & landed value; export value; wholesale value; retail value \\
\hline Wellbeing Index & $\begin{array}{l}\text { OECD Better Life Index; Genuine Progress Index; } \\
\text { Gross National Happiness; Human Development Index }\end{array}$ \\
\hline
\end{tabular}


Appendix 2. Evaluation Framework for Sustainable Fisheries 2.4 - Sample Research Questions.

Ecological Domain

\begin{tabular}{|c|c|}
\hline Element & Questions \\
\hline Productivity & $\begin{array}{l}\text { Have the appropriate metrics of productivity been identified for the population (e.g. } \\
\text { abundance, biomass, spawner density (egg production), growth rate, body size, body } \\
\text { condition, age structure, gonadal somatic index, mortality)? Are these metrics } \\
\text { measured, monitored, known, estimated? How are these metrics measured, monitored, } \\
\text { estimated? Are constraints on harvesting and incidental mortality, e.g. limit reference } \\
\text { points, appropriately used to achieve maximum sustainable yield (MSY) and avoid } \\
\text { growth and recruitment overfishing? }\end{array}$ \\
\hline $\begin{array}{l}\text { Spatial and Temporal } \\
\text { Dynamics }\end{array}$ & $\begin{array}{l}\text { Have spatial scales of population organization been identified (e.g. single site, multiple } \\
\text { sites, regions)? Has the range of a population's distribution at different spatial scales } \\
\text { been identified? Do identified spatial scales match up with the spatial scale of } \\
\text { management and assessments? Are migration routes variable over time and space } \\
\text { (e.g. annually, in-season)? What vital rates (e.g., recruitment, mortality, survival, } \\
\text { fecundity, dispersal of larvae), or dynamic variables can influence the spatial } \\
\text { distribution of a populations? Are rates/migration routes measured? }\end{array}$ \\
\hline $\begin{array}{l}\text { Phenotypic \& Genetic } \\
\text { Diversity }\end{array}$ & $\begin{array}{l}\text { Has a scale of population unit been established (e.g., conservation units, runtime } \\
\text { groups, life history groups)? Are life-history traits (e.g. age-at-maturity) quantified and } \\
\text { monitored? Is genetic variability within a population measured? }\end{array}$ \\
\hline Substrate Quality & $\begin{array}{l}\text { Has the nature, type, and extent of important habitat substrate been identified, } \\
\text { quantified and monitored for all stages of life cycle? Are substrate quality variables (e.g. } \\
\text { dominant substrate, substrate material, substrate size, presence of riffles and pools) } \\
\text { monitored? }\end{array}$ \\
\hline Water Quality & $\begin{array}{l}\text { Have water quality standards been identified? Are water quality variables (e.g. } \\
\text { dissolved oxygen, pH, conductivity, salinity, temperature, and dissolved organic } \\
\text { carbon) monitored? }\end{array}$ \\
\hline Productive Capacity & $\begin{array}{l}\text { Have the physical and biological characteristics of the habitat been identified? Have } \\
\text { key parameters been identified to quantify the capacity of a habitat (e.g. population } \\
\text { carrying capacity, production rate, biodiversity)? Are these parameters measured, } \\
\text { estimated and monitored? Have historic changes to habitat capacity been identified? }\end{array}$ \\
\hline Biodiversity & $\begin{array}{l}\text { Have the key measures of biodiversity been identified? How many species are in the } \\
\text { ecosystem (e.g. species richness, evenness and density, the Simpson index and } \\
\text { Shannon index) monitored? Is species richness (number of species), evenness (how } \\
\text { evenly distributed are species Are indices of biodiversity calculated (e.g., Simpson's } \\
\text { Index, Shannon's Index)? }\end{array}$ \\
\hline Food Webs & $\begin{array}{l}\text { Have food chains, food webs and energy flows between trophic levels been identified } \\
\text { within the ecosystem. What is the length of the food chains that make up the } \\
\text { ecosystem foodweb? Are there keystone species? Are there known disruptions to food } \\
\text { webs (e.g., discard events, major die-offs, extirpations, predator-prey interactions). } \\
\text { Trophic cascades? }\end{array}$ \\
\hline
\end{tabular}




\begin{tabular}{ll}
\hline Element & Questions \\
\hline Regime Shifts & Is there identification of historical or potential future regime shifts in the ecosystem? \\
& Are indicators for regime shifts identified and monitored? Have there been any long- \\
& term ecosystem reorganizations (e.g., change in dominant species, change in primary \\
& producers)?
\end{tabular}

Social and Economic Domain

\begin{tabular}{|c|c|}
\hline Element & Questions \\
\hline Material Wellbeing & $\begin{array}{l}\text { Are basic necessities for life acknowledged within the fisheries management system - } \\
\text { access to food in particular? Are basic necessities of life available - water, food, } \\
\text { shelter? }\end{array}$ \\
\hline Relational Wellbeing & $\begin{array}{l}\text { Does the fisheries management system recognize and support the development and } \\
\text { maintenance of healthy social networks, or does it promote an adversarial approach } \\
\text { that breaks down networks? Does the management agency have good working } \\
\text { relationships with fishery participants and fishery stakeholders? }\end{array}$ \\
\hline Subjective Wellbeing & $\begin{array}{l}\text { Do participants in the fishery have a positive view of their fishery and their participation } \\
\text { in the fishery? Does the society at large view the fishery and fishery participants } \\
\text { positively? Is there a positive view of the management agency by fishery participants } \\
\text { and society at large? Does the management agency have a positive view of the fishery } \\
\text { and fishery participants? }\end{array}$ \\
\hline Efficiency & $\begin{array}{l}\text { Is there a commitment to efficient fisheries operations that are not wasteful and do not } \\
\text { displace costs onto other participants or society at large? Is there an excessive amount } \\
\text { of discard mortality? Is the fishing fleet highly polluting? Does the type of fishing (gear, } \\
\text { timing) result in product that is of a much lower value than could be achieved with other } \\
\text { fishing methods? }\end{array}$ \\
\hline Viability & $\begin{array}{l}\text { Are the majority of enterprises at all stages of the value chain, from harvester to off } \\
\text { loader to processor to retailer to support services (e.g., boat works, gear suppliers) able } \\
\text { to earn a living wage and sufficient income to reinvest and sustain their enterprise over } \\
\text { the medium and long term? }\end{array}$ \\
\hline Equity & $\begin{array}{l}\text { Is there consideration of the distribution of the costs and benefits associated with } \\
\text { management decisions? Is there a full cost accounting approach taken that recognizes } \\
\text { not just revenue but also operating costs and income of participants in the fishery? }\end{array}$ \\
\hline Poverty \& Livelihoods & $\begin{array}{l}\text { Is there consideration of who will bear the majority of the costs associated with } \\
\text { management decisions and if there are individuals or groups that will bear a } \\
\text { disproportionate cost? Will those least able to bear additional costs or reduced income } \\
\text { be negatively impacted? Do people have opportunities to have a sustained livelihood } \\
\text { within the fishery? Are participants able to earn a living in a meaningful way that } \\
\text { encompasses the capabilities, assets, income and activities required to secure the } \\
\text { necessities of life? }\end{array}$ \\
\hline Women \& Gender & $\begin{array}{l}\text { Is there consideration of the impact of fisheries management decisions on women? Are } \\
\text { management decisions taken with consideration of the jobs that women traditionally } \\
\text { occupy in the fishery? }\end{array}$ \\
\hline
\end{tabular}




\begin{tabular}{ll}
\hline Element & Questions \\
\hline Fishing Communities & $\begin{array}{l}\text { Is there regional and place-based analysis of the consequences and impacts of } \\
\text { fisheries management? Are the impacts of management decisions considered on the } \\
\text { basis of individual communities? }\end{array}$ \\
Indigenous Peoples & $\begin{array}{l}\text { Is there recognition of the rights of indigenous peoples? Are there mechanisms in place } \\
\text { to ensure meaningful participation of indigenous peoples in management activities? }\end{array}$ \\
Future Generations & $\begin{array}{l}\text { Is there consideration of the impacts on youth and on future generations? Are there } \\
\text { mechanisms to ensure intergenerational transfer of knowledge, skills and assets? Are } \\
\text { the long term consequences of fisheries management addressed? }\end{array}$
\end{tabular}

\section{Governance Domain}

\begin{tabular}{|c|c|}
\hline Element & Questions \\
\hline Purpose & $\begin{array}{l}\text { What is the process intended to accomplish, why does it exist? What are the main } \\
\text { ecological, social and economic goals and objectives of the process? Who established } \\
\text { the goals and objectives, the management authority, stakeholders and other parties or } \\
\text { some combination of both? }\end{array}$ \\
\hline Scope & $\begin{array}{l}\text { Who is involved in the process? Who are the main players, in terms of groups or } \\
\text { individuals that participate? Is the process geographically bounded, and if so, how are } \\
\text { those boundaries defined? What are the timelines involved? Is documentation relating } \\
\text { to the process available? When was the process established? }\end{array}$ \\
\hline Rules & $\begin{array}{l}\text { Is the process grounded in explicit policies, laws or regulatory frameworks? Does the } \\
\text { process have a written or commonly understood vision or mandate? Are there } \\
\text { operating agreements and/or terms of reference to guide how participants in the } \\
\text { process interact and behave? How is success or failure in relation to goals and } \\
\text { objectives to be measured and who decided the measurement criteria? }\end{array}$ \\
\hline Resources & $\begin{array}{l}\text { What resources are available to support the process? This includes human resources, } \\
\text { e.g. dedicated staff, consultants and support services, technical resources and financial } \\
\text { resources. Who provides resources, the management agency, other parties or both? }\end{array}$ \\
\hline Collaborative & $\begin{array}{l}\text { How does the process support the ability of parties to work together towards a common } \\
\text { goal or set of goals? Is there access to professional facilitation, dispute resolution } \\
\text { mechanisms, or methods such as structured decision-making? Is there a "level playing } \\
\text { field". If not what methods are used to address imbalances between participants? }\end{array}$ \\
\hline Transparent & $\begin{array}{l}\text { Is all the necessary information available to participants to support informed decision- } \\
\text { making? Is the rationale behind decisions clearly stated and made widely available? } \\
\text { Do all parties have support to understand technical information on which decisions } \\
\text { depend? Are trade offs (ex. among domains and dimensions) explicitly discussed and } \\
\text { represented? }\end{array}$ \\
\hline Inclusive & $\begin{array}{l}\text { Are all parties with a legitimate interest involved in the process? Are resources } \\
\text { provided to ensure that participants can be involved without disadvantage due to lack } \\
\text { of financial, human or technical resources? }\end{array}$ \\
\hline Predictable & $\begin{array}{l}\text { Does the process operate according to clearly defined principles and rules that all } \\
\text { parties understand and have agreed to? Are decisions consistent with those rules? }\end{array}$ \\
\hline
\end{tabular}




\begin{tabular}{ll}
\hline Element & Questions \\
\hline Flexible & $\begin{array}{l}\text { Is the process capable of being adapted to changing circumstances? How responsive } \\
\text { is the process to changing conditions, both external variables, such as environmental } \\
\text { factors or political priorities, and internal variables such as changes in personnel or } \\
\text { funding? }\end{array}$ \\
Accountable & $\begin{array}{l}\text { Are there mechanisms to remove or sanction individuals or groups if there is } \\
\text { agreement that they have not carried out their responsibilities to the satisfaction of }\end{array}$ \\
participants in the process and/or those they represent and serve? & Are there periodic evaluations of the institutional arrangements and the decision- \\
Effective & making process that are objective and comprehensive? Are the results of these \\
& evaluations communicated to participants and other interested parties? \\
& Does the process produce outcomes that are generally seen as fair and reasonable \\
Legitimate & regardless of who benefits? Do participants abide by and comply with decisions \\
& regardless of whether or not they agree with them?
\end{tabular}

